\title{
Justicia efectiva, igualdad real de las partes en el proceso laboral, y rapidez procesal por un derecho del trabajo procesal
}

\author{
Francisco Pérez Amorós \\ Espanha \\ perez_amoros@hotmail.com \\ Catedrático de Derecho del Trabajo y \\ de la Seguridad Social de la Universidad \\ Autónoma de Barcelona (España).
}

Recebimento do artigo: 25/06/2009

Aprovado em: 10/12/2009

\section{Resúmen}

Partiendo de la idea que el derecho en general no debe tratar siempre igual a todos, sino de forma desigual cuando regula las relaciones entre desiguales, trataremos en este estudio del por qué y del cómo el Derecho del Trabajo Procesal ocupa un lugar relevante entre los mecanismos sociales establecidos para enmendar desigualdades sociales por medio de técnicas compensatorias. Los clásicos principios que inspiran el proceso laboral pretenden destruir el mito de la "verdad formal" a favor de la "verdad real o material", y para ello, resulta necesario que toda la actividad probatoria del mismo transcurra bajo el imperio de la igualdad real de las partes procésales, para lo que se reclama del juez una especial actuación tutelar del trabajador. El tradicional debate sobre el predominio de la oralidad del proceso laboral y la consiguiente celeridad procesal viene a reconocer que sólo la igualdad real de los sujetos procésales garantiza la verdadera libertad de los mismos.

\section{Palabras-clave}

Procedimiento laboral. Derecho Procesal Laboral. Principios del proceso laboral. 


\title{
Effective justice, real equality of the parties in the labor process and procedural celerity
}

\author{
for a Labor Law Process
}

\author{
Francisco Pérez Amorós
}

\section{Abstract}

Based on the idea that generally law should not treat everyone equally, but unequally, when it regulates the relations between unequal, we are going to try to understand in this study why and how the Procedural Labor Law has a special place among the social mechanisms established to correct social inequalities through compensatory techniques. The classic principles which inspire the Labor process intend to destroy the myth of "formal truth" in favor of the "material or real truth", and it seems therefore to be necessary that any evidence of that activity takes place under the rule of true equality of the litigants, so that one demands the judge a special guardianship of the employee performance. The traditional debate about the prevalence of oral form in the labor processes and the subsequent procedural celerity allow the recognition that only true equality of procedural parties guarantees a true freedom for themselves.

\section{Key-words}

Labor law. Labor procedure. Principles of procedural labor law. 


\section{Sumário}

Introducción.

I Prévias.

II Breve reseña normativa.

III Principios inspiradores del proceso laboral.

IV Los criterios ordenadores del procedimiento laboral.

V El especial reflejo de los principios del proceso y de los criterios del procedimiento en la fase probatoria.

Conclusión.

Referências Bibliografía.

\section{Introducción}

1. En las escasas páginas que siguen, se recoge en lo fundamental nuestra intervención en el "I Congreso de Derecho Procesal del Trabajo" celebrado los días 25 a 27 de marzo de 2009, en la Ciudad de Santo Domingo (República Dominicana) bajo el auspicio, entre otras entidades, de la Asociación Iberoamericana de Derecho del Trabajo y de la Seguridad Social y de la Academia Iberoamericana de Derecho del Trabajo y de la Seguridad Social. Reitero, aquí y ahora por escrito, mi agradecimiento y felicitación a los organizadores, por invitarme a participar y por la organización y celebración del evento, respectivamente; parabienes, que si se nos permite, personalizamos en el Dr. Don Manuel Ramón Herrera Carbuccia - Presidente del Comité Organizador -, con el ruego - seguramente innecesario conociendo su buen saber personal y mejor hacer institucional - que los extienda a todas y cuantas personas colaboraron en el éxito de un evento, que se desarrolló con rigor científico y resultó rebosante de cordialidad y amistad.

2. Por lógico y respetable indicación de los organizadores, de la misma manera que mi exposición oral tuvo que ser breve, también lo deben ser estas notas escritas: se trató y trata de poner negro sobre blanco algunas reflexiones en voz alta sobre el tema precisado en cabecera. Nadie espere pues un repaso detallado del 
tema, ni tampoco, claro está, un estudio con abundantes citas y fundamentos a la luz de la normativa de ritual vigente en España, pues de nada de ello se trataba ni se pretende hacer por razones obvias derivadas de las características del evento.

\section{Previas}

3. Presentaremos a continuación cuatro afirmaciones - previas - con la finalidad de alcanzar lo más rápido posible un doble objetivo: resumir en unas pocas ideas eje el hilo común que impregnará todo aquello que expresaremos después; y a su vez, dejar entrever desde buen principio cuál será el orden que seguiremos en nuestra exposición.

Tales asertos son del siguiente tenor y contenido:

$\left.1^{\circ}\right)$ En unos tiempos en los que el liberalismo económico - y el político - ha puesto de manifiesto de nuevo sus limitaciones intrínsecas, y lo ha hecho con la crudeza que ponen de relieve los nefastos efectos sociales derivados de la actual crisis económica, no parece de recibo ni provechoso seguir reivindicando, simplemente, la necesidad de la justicia y la bondad de la igualdad, sino que un discurso iuslaboralista de progreso debe basarse en la reclamación de una justicia efectiva y una igualdad real, si como es nuestro caso, se tiene como horizonte una democracia real por social, plural y avanzada y se acepta que lo que, sustancialmente, diferencia la irquierda de la derecha es la defensa de la igualdad de las personas, y así es, porque parafraseando estudioso solvente, de la igualdad depende la libertad y la paz. ${ }^{1}$ Los adjetivos calificativos "efectiva y real- antecitados siguen teniendo naturaleza y cualidad gramatical de tales, pero su profundo sentido ideológico hace de los mismos referentes de primer orden para delimitar los sustantivos a los que acompañan: una justicia y una igualdad formales, no son tales, son entelequias más interesadas que interesantes; lo que nos debe preocupar es que los derechos sociales se puedan ejercer de forma real y eficaz, lo precisaremos en un momento posterior, pero, ya podemos afirmar que la seguridad jurídica que aporta el Derecho también debe ser una seguridad en punto al goce de los derechos.

Reclamar una justicia y una igualdad de tal condición casa bien con un Estado social. Un modelo de organización política de tal naturaleza, a diferencia de un

BOBBIO, N. Derecha e izquierda. 3. ed. Madrid: Suma de Letras, S.L. (Punto de Lectura), marzo, 2001. p. 133. 
Estado liberal, no se debe contentar con que los poderes públicos se diferencien y respeten entre si y sometan al derecho (eso es simplemente un Estado de Derecho), ni con pretender además una igualdad formal entre las personas y grupos sociales (eso es un Estado de Derecho liberal: liberalismo, formalismo, individualismo), sino que debe actuar políticamente tan apegado al realismo social (intervencionismo y pluralismo) como resulte necesario para asegurar, en definitiva, que la libertad y la justicia sean realmente efectivas y eficazmente reales para todos en todo momento y en toda situación.

$\left.2^{\circ}\right)$ Existe una opinión generalizada sobre el hecho de que no pocas (des) igualdades y no menos (in)justicias tienen su principal origen - a la vez que campo abonado para su continuada (re)producción - en la regulación de las relaciones sociales derivadas de las de producción de un sistema capitalista: el trabajo (decente) dignifica a la persona, cierto es, pero también puede ocurrir en no pocas ocasiones que el trabajo (indigno) la denigre.

$\left.3^{\circ}\right) \mathrm{Y}$ así mismo existe cierto consenso en defender que el Derecho del Trabajo ocupa un lugar relevante entre los mecanismos sociales establecidos para enmendar dichos desequilibrios sociales. El Derecho del Trabajo es uno de los frutos de aquel pacto político suscrito entre el mercado y el Estado - superando así el puro liberalismo y sus efectos sociales no deseados - que posibilita que éste intervenga en la ordenación de aquél regulando las relaciones laborales y los conflictos surgidos de las mismas, pacto del cual deberemos en su momento predicar su actualidad; el Derecho del Trabajo pues colabora en la búsqueda de los nuevos equilibrios socio-políticos que pretende establecer el pacto del que procede, y es por ello que su función es la de reequilibrar situaciones personales entre trabajadores y empresarios cualquiera que sea el escenario en el que se interrelacionen en condición de tales. El Derecho del Trabajo ordena el contenido de las relaciones laborales utilizando para ello la desigualdad compensatoria igualatoria: tratar de forma desigual a dichos desiguales, es el mejor de los manejos posibles del venerado principio de igualdad, naturalmente, si lo que pretendemos es que la igualdad sea real y no simplemente formal. El Derecho del Trabajo es en cuerpo y alma pura y dura dialéctica pues tanto es un factor potencial de progreso social como de estabilidad para un modelo económico a la vez que de un sistema político, pero en todo caso, tratar sobre el por qué y el para qué del mismo siempre conduce, en nuestra opinión, a una misma y única respuesta: para prevenir y reparar el conflicto social en favor de los trabajadores; o 
dicho sea en palabras del propio Tribunal Constitucional, el Derecho del Trabajo es "un ordenamiento compensador e igualador que corrige(...) las desigualdades existentes". ${ }^{2}$ Es en este sentido en el que en otro foro hemos presentado al Derecho del Trabajo - ya sea en su faceta sustantiva como procesal - como "un derecho revolucionario en pro del derecho a la paz": ${ }^{3}$ revolucionario por su potencial para coadyuvar a transformar una realidad social, y pacífico porque equiparando las armas de los contendientes compone el conflicto social con el deseado equilibrio; y no se entienda contradictorio ribetear de pacifico a tal Derecho con el hecho de utilizar de términos supuestamente belicosos para así hacerlo, pues no debemos olvidar que lo que tal ordenamiento pretende es, precisamente, componer y superar un conflicto tan real como significado y - en si mismo considerado - nada patológico como lo es el conflicto social, es decir, el conflicto por excelencia del que su enraizada historia - tanto como los tiempos mismos - demuestra que ha sido el motor de no pocos y profundos cambios sociales.

Y llevando el discurso a derroteros más concretamente procesales que son los que nos ocupan, y por lo que después expondremos, conviene enfatizar desde ahora que la multiajenidad con la que el trabajador presta sus servicios no sólo le somete a las desigualdades sustantivas que el ordenamiento jurídico laboral material intenta corregir en los términos expuestos, sino también a desigualdades adjetivas o procesales que, consecuentemente, persiguen superar las normas procesales laborales ${ }^{4}$. Esta es una manera abreviada como otra de avanzar en nuestra exposición pues nos permite afirmar de forma razonada que el Derecho Procesal Laboral - y por ende todas sus instituciones, categorías y técnicas jurídicas - también debe ser considerado como un derecho tuitivo de los trabajadores en cuanto sujetos procesales, pues en este escenario también están en situación de clara desventaja en relación a su contraparte, ideas estas aquí sintetizadas pero que tuvimos la oportunidad de detallar en otro momento ${ }^{5}$. Si partimos de la hipótesis que el derecho laboral material

$2 \quad$ STC 20/1984, de 13 de febrero. Un comentario sobre tal sentencia. En: GARCÍA-PERROTE ESCARTÍN, I.: La prueba en el proceso de trabajo. Madrid: Civitas, 1994, especialmente, págs. 83 y ss.

3 PÉREZ AMORÓS. F. El derecho del trabajo un derecho revolucionario en defensa del derecho a la paz. En: PALOMINO, TA. El Derecho del Trabajo Iberoamericano. Libro homenaje al Dr. Baltasar Cavazos Flores. Lima: Imprenta Gráfica E\&N. Asociación Iberoamericana de Derecho del Trabajo y de la Seguridad Social, 2005, p. 370-391.

4 PALOMINO, T.A. Derecho del Trabajo en el siglo XXI. Lima: Editorial Juris Laboral, 1994.

5 PÉREZ AMORÓS, F.: Nociones sobre el recurso de casación para la unificación de la doctrina en el derecho procesal español, en: HERRERA CARBUCCIA, MR. (Coord.). Estudios de procedimiento laboral en Iberoamericana. Homenaje a Don Rafael Alburquerque. 
está inspirado en el principio interpretativo pro operario del cual penden los de carácter aplicativo del mismo, por coherencia, debemos defender que el derecho laboral adjetivo o de ritual - y todas sus instituciones y categorías - debe interpretarse de acuerdo con el principio tutelar procesal del que dependerán ciertos criterios aplicativos. Dicho sea en los propios términos en los que se ha pronunciado el Tribunal Constitucional en una sentencia que fue pionera y sigue siendo ejemplar:

el Derecho laboral... se constituye como un ordenamiento compensador e igualador... de las desigualdades fundamentales (entre trabajador y empresario)... a esta finalidad sirven no sólo las normas sustantivas, sino también las procesales, porque superando tendencias que creían que el Derecho procesal era un conjunto de normas neutras y aisladas del Derecho sustantivo, resulta patente que ambos son realidades inescindibles, actuando aquél como un instrumento más, y de singular importancia, para el cumplimiento de los fines pretendido por éste; ${ }^{6}$

posicionamiento del referido Tribunal que se puede cohonestar con aquellas aportaciones doctrinales que presentan al Derecho Procesal Laboral como un "instrumento para la promoción, propulsión y actuación del Derecho del Trabajo"7, y que defienden que "el principio protector del trabajador - que es la esencia del derecho laboral sustantivo - está también en la base, en el código genético del derecho pro-

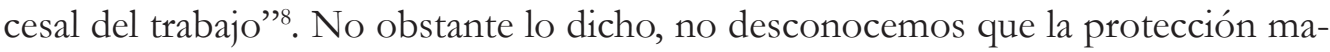
terial del Derecho del Trabajo y la tutela del Derecho Procesal del Trabajo no son idénticas, pues la lógica procesal responde a intereses distintos que los que tutelan las normas materiales, de la misma manera que la función del juez no es la misma que la del legislador.

Es por ello que, quizás, más que referirnos a un Derecho Procesal Laboral deberíamos hacerlo a un Derecho del Trabajo Procesal (sic). Recurso expositivo este al que nos acogemos para poder pergeñar una idea de mayor calado que, en estas previas, sólo dejamos apuntada, cual sería reconsiderar la conveniencia de volver a pensar en un Derecho Social como la rama social del Derecho, omnicomprensivo, tanto de la regulación laboral y de la procesal del trabajo, como de la protección social, un

Republica Dominicana: Asociación Iberoamericana de Derecho del Trabajo y Librería Jurídica Internacional., 2007, Tomo II, págs. 469 a 516, y por lo que aquí puede interesar en especial, ver apartado "II.-Derecho del Trabajo y Derecho Laboral Procesal: "realidades inescindibles", págs. 472 a 477.

6 STC 3/1983, del 25 de enero del Pleno del TC (BOE, 17 de febrero, corr. err. BOE de 9 de marzo), en su Fundamento Jurídico Tercero, párrafo 5.

7 SANZ TOMÉ F. La prueba en el proceso laboral. Comentarios-Sentencias. Valladolid: Lex Nova, 1990, Tomo I, pág. 1.

8 PASCO COSMÓPOLIS, M. Principio protector en el proceso laboral, en HERRERA CARBUCCIA, MR. (Coord.). Estudios de Procedimiento Laboral en Iberoamerica. Republica Dominicana:. Asociación Iberoamericana de Derecho del Trabajo., 2007, Tomo I, pág. 71. 
Derecho Social, que como bien se ha argumentado es "el reconocimiento de que los seres humanos no somos todos iguales"; planteamiento común este que permitiría advertir con más claridad que el principio pro operario y su homónimo, el principio tutelar procesal, en puridad, pueden ser tenidos como un mismo principio, o si se prefiere como las dos caras de uno mismo pues ante la disparidad social la (des) igualación compensatoria no se agota con la normativa material sino que debe seguir prosperando con las normas procesales; proposición esta, que por lo demás ya está, en parte, puesta en práctica, pues ocurre que, por ejemplo, ya nos referimos a la protección social, pero es más, al tratar del orden de la jurisdicción que conoce de los litigios laborales, el propio legislador no se refiere al orden laboral, sino que lo hace, expresa y literalmente, al orden social de la jurisdicción o al orden jurisdiccional social (arts. 1 y 74 del TRLPL).

Por lo que aquí nos interesa, debemos añadir que esta socialización de todo lo jurídico-laboral también responde a que las citadas relaciones laborales y las relaciones procesales subsiguientes propias de un modelo de producción capitalista puro, además de tener un componente individual del que traen causa los conflictos individuales, también tienen una dimensión colectiva derivada de la escisión de la sociedad en clases sociales y de los conflictos sociales que se dan entre las mismas, resultando de todo ello que una democracia política real por "avanzada" - para utilizar el propio lenguaje del Preámbulo de nuestra Constitución vigente - y en consecuencia un Derecho del Trabajo tuitivo y un Derecho Procesal Laboral tutelar- no sólo debe garantizar una justicia efectiva a la par que una igualad real a las personas individualmente consideradas, sino que también debe procurar el mismo trato a las clases sociales: el conflicto que ocupa y preocupa al ordenamiento laboral, tanto material como procesal, no es sólo el conflicto individual, sino, especialmente, el conflicto social; lo tuitivo del ordenamiento laboral, tanto material como procesal, se proyecta tanto sobre los trabajadores, como sobre la clase social que los mismos conforman. Abundando en la referida socialización y prosperando más en nuestro relato podemos dejar dicho -para después recuperar esta idea- que: si el reconocimiento de la libertad sindical en el marco de las relaciones laborales es una de las mejores maneras de explicitar tal socialización del ordenamiento laboral, el reconocimiento de la intervención del sindicato en el proceso hace lo propio en punto a las relaciones procesales.

$\left.4^{\circ}\right)$ Y por último, y ubicándonos ya en el núcleo más duro del proceso laboral, es decir en la denominada fase probatoria - una de las más directamente relacionada con la búsqueda y fijación de la verdad sobre

RUIZ MORENO, AG. Nuevo Derecho de la Seguridad Social. México: Ed. Porrúa. 2003 (Séptima edición), pág. 3. 
la se construye la decisión judicial - es cuando el carácter tutelar del ordenamiento procesal en pro del imperio de la justicia efectiva y la igualdad real debe excitar más el empeño de los poderes públicos: debemos evitar caer en el error de seguir, estérilmente, polemizando sobre si la verdad procesal es la formal o la material; ya lo dijo el clásico - "el mito de la verdad formal fue destruido por Carnelutti" ${ }^{10}$-, verdad, por definición, sólo puede haber una (la material/la real), la otra (la formal), no lo es aunque por pura conveniencia convengamos lo contrario: "La verità non possa essere che una, onde la vierità formale o giuridica o coincide con la verità materiale, e non è che verità, o en divierge, e non è che una non verità" ${ }^{11}$. Las reglas de ritual que regulen la fase probatoria, deben, por todo ello, restaurar, con más celo que nunca, la igualdad real entra las partes en conflicto, y hacerlo de tal manera que lo juzgado y ejecutado responda a criterios de una auténtica justicia efectiva: "El fin del proceso del trabajo es la búsqueda de la verdad material". ${ }^{12}$ Como detallaremos - y ahora citamos a modo de simple v. gr .-, para conformar una verdad hay que tomar en consideración que la accesibilidad a ciertas pruebas y la disponibilidad de las mismas no resulta ser la misma por parte de quien es el titular del poder de organización de la empresa que por quien está sometido o queda subordinado al mismo, y por ello resulta necesario que el legislador procesal remueva este obstáculo probatorio con un trato desigual a las partes procesales si es que se quiere que el proceso alcance el buen fin que le es propio, planteamiento que, además, responde al realismo jurídico del que tantas concreciones se han recogido y se continúan incluyendo en el Derecho Social.

4. Los cuatro anteriores asertos bien podrían ilustrarse a la vez que fundarse con la cita de no pocas referencias normativas españolas de orden procesal, a cual más relevante, pero compelidos a tener que hacerlo sólo con una, nos inclinamos por traer a colación aquel mandato procesal - quizás no el más pomposo de los posibles, pero si muy rotundo y expresivo - que obliga a los propios "órganos judiciales", nada más ni nada menos que a corregir "los actos que, al amparo del texto de una norma, persigan un resultado contrario al previsto en la Constitución y en las leyes para el equilibrio personal, la tutela judicial y la efectividad de las resolucio-

$\overline{10}$ MONTERO AROCA, J. Particularidades de la prueba en el proceso laboral. Procedimiento, objeto y medios. Especial referencia a la prueba documenta, en AGUSTÍ JULIÀ, J. La prueba en el proceso laboral. Cuadernos de Derecho Judicial (1997). Madrid: Escuela Judicial. Consejo General del Poder Judicial, 1998, pág. 186.

11 CARNELUTTI, M. La prova civile. Milano: Giuffrè. 1992, pág. 29.

12 RODRÍGUEZ-PIÑERO, M. Derecho del Trabajo y proceso. Murcia: Publicaciones Escuela Social de Murcia, 1972, pág. 12. 
nes", precepto que se contempla en el Texto Refundido de la Ley de Procedimiento Laboral aprobado por el Real Decreto Legislativo 2/1995, de 7 de abril (en adelante, TRLPL) (BOE, 11 de abril). ${ }^{13}$ Tenemos para nosotros que no se requiere un largo discurso para poder deducir de tal cita procesal y hacerlo con plenas garantías de éxito, que el legislador, influido por el principio tutelar que adorna el ordenamiento procesal, configura un proceso laboral al servicio no de cualquier tipo de justicia e igualdad entre las personas, sino de la efectiva y real, respectivamente. Al estudio más detallado del significado y proyección de dicho mandato legal procesal y al del sentido de nuestra consiguiente afirmación volveremos líneas y páginas abajo; aquí y ahora sólo queremos dejar mayor constancia del didáctico y rico sentido de algunos de los términos que utiliza al efecto, tales como, v. gr.: "equilibrio" (por igualdad real, decimos nosotros)... "tutela" y "efectividad"; elocuencia del legislador procesal que alcanza su justo tono con tan sólo aprovechar la ocasión para adelantar - aunque de momento sea en nota a pie de página - los contenidos de los pasajes 9.2 y 24 de nuestra Constitución (en adelante, CE) ) $^{14}$, y poder comprobar así la correlatividad, terminológica y conceptual, que existe entre el mandato procesal transcrito y los constitucionales referidos.

Y a su vez, las cuatro afirmaciones anteriores, nos facultan, como teníamos previsto, para poder adelantar el orden de nuestro relato: tras una primera y breve referencia normativa (infra II) que nos servirá de base y fundamento, pasaremos, en segundo término, a tratar de la configuración del proceso laboral y de los principios que lo inspiran (infra III), para después hacer lo propio con la ordenación del consiguiente procedimiento laboral y de los criterios utilizados al efecto (infra VI), y en cuarto y último lugar, pondremos especial atención en señalar, como los principios del proceso y los criterios del procedimiento tienen una pero que muy especial proyección en la fase probatoria del procedimiento laboral (infra V). Con tales reflexiones así encadenadas trataremos de comprobar críticamente como tales instituciones, categorías y criterios están al servicio del derecho que todas las personas - trabajadores/demandantes en nuestro caso - tienen a disfrutar de una tutela judicial, precisa y realmente, "efectiva". ${ }^{15}$

13 Art. 75.1 del referido TRLPL; cuerpo legal del que por su importancia señalaremos infra otras cuestiones generales en el apartado "II. Breve reseña normativa".

14 La Constitución española vigente es de fecha de 7 de diciembre de 1978 (BOE, 29 de diciembre). Su ordinal 9.2 previene, por lo que aquí nos interesa, lo siguiente: "Corresponde a los poderes públicos promover las condiciones para que la libertad y la igualdad del individuo y de los grupos en que se integra sean reales y efectivas; remover los obstáculos que impidan y dificulten su plenitud(...)"; y su pasaje 24.1, establece el siguiente derecho subjetivo de rango fundamental: "Todas las personas tienen derecho a obtener la tutela efectiva...sin que, en ningún caso, pueda producirse indefensión”.

15 El art. 24.1 de la Constitución española de 27 de diciembre de 1978, preceptúa que: "Todas las personas tienen derecho a obtener la tutela efectiva de los jueces y tribunales(...)". 
Anticipado lo que trataremos, debemos reconocer que muchos son los aspectos que deberán quedar en el olvido por razones obvias. Una manera de limar los efectos negativos de tales vacíos, es recurrir a formular dos precisiones de muy dispar condición. La primera para apuntar que la tutela judicial imprime su carácter en todas las actividades propias de la potestad jurisdiccional - cuando se juzga ( $v$ gr: fase probatoria) y cuando se ejecuta lo juzgado ( $v \cdot g r$. ejecución de sentencias) -; en estas páginas dedicamos especial atención al primer supuesto, pero no desconocemos que "difícilmente pueda hablarse de la existencia de un Estado de Derecho cuando no se cumplen las sentencias y demás resoluciones judiciales firmes”16 (arts. 117 y $118 \mathrm{CE}$ ), ni tampoco que

La ejecución de las sentencias forma parte del derecho a la tutela efectiva de los Jueces y Tribunales ya que, en caso contrario, las decisiones judiciales y los derechos que en las mismas se reconocen o declaran no serían otra cosa que declaraciones de intenciones sin alcance práctico ni efectividad alguna. ${ }^{17}$

Y una segunda precisión que nos permita manifestar que la intención que nos mueve al redactar estas páginas es la de contribuir a que con el paso del tiempo cada vez existan menos razones para que, en bien de la democracia avanzada y pluralista, los trabajadores desconfíen de la justicia y que cada vez resulte más incierta la clásica frase de Ovidio - Curia pamperibus clausa est - que muchos y clásicos críticos han recordado con ocasión de formular sus reservas sobre las leyes procesales sociales del pasado. ${ }^{18}$

\section{Breve reseña normativa}

5. Según lo previsto, presentamos en este segundo apartado una somera cita glosada de aquellas normas españolas vigentes que fundamentan y cohesionan las cuatro consideraciones generales que hemos formulado en el introito y las más particulares que seguirán; reseña que deberá ser concisa por razones obvias y más que deberá serlo por cuanto que,

\footnotetext{
16 SALINAS MOLINA, F. Principios de la nueva regulación de la ejecución, en: ALARCÓN, MR. (Coord.). Estudios de la Ley de Procedimiento Laboral de 1990. Madrid:. Marcial Pons, 1991, pág. 323.

17 STC 18/1997, de 10 de febrero. Pronunciamiento que ha servido de base para otras sentencias posteriores del propio Tribunal Constitucional, $v$. gr., STC 92/2998, de 7 de abril (BOE de 20 de mayo de 1998).

18 SALVIOLI, G. El derecho civil y el proletariado. Edición de Bartolomé Clavero. Sevilla: Edita, Secretariado de Publicaciones de la Universidad de Sevilla, 1979. En especial sobre “Leyes Procesales”, págs. 123 y ss.; y la cita de Ovidio en pág. 123.
} 
como hemos acotado supra, nuestras opiniones deben ser y serán de tono tan general como reflexivo.

6. Como no podía ser de otra manera, pues de todos es conocido que "Es fácil apreciar cierto paralelismo entre la disciplina del proceso y el régimen constitucional en el que se desenvuelve", ${ }^{19}$ nuestro primer reclamo debe ser para la ya citada Constitución de 27 de diciembre de 1978, texto, cuyo rico lineamiento sociolaboral, y cuyo carácter normativo - dos de los referentes caracterizadores de tal cuerpo legal -, hacen del mismo, y respectivamente, una auténtica norma social a la vez que una norma de normas. A una Constitución así caracterizada por su contenido y naturalezaza quedan sometidos los tres poderes públicos del Estado; y pasando de lo general a lo particular, podemos apuntar que los mandatos de tal alta norma también obligan a todos los jueces y tribunales a interpretar y aplicar todas las normas de acuerdo con los preceptos constitucionales, y a que así lo hagan a lo largo de todo el proceso y cualquiera que sea la modalidad del mismo. ${ }^{20}$

Así pues, todos los órganos del orden social de la jurisdicción también deberán cumplir con lo preceptuado en dos pasajes constitucionales de los que ya hemos efectuado una primera pero tímida aproximación, y a los que aquí y ahora prestaremos mayor consideración, aunque advertimos que esta no será la postrera vez que los citaremos. La CE, en su artículo 1.1 establece que: "España se constituye en un Estado social y democrático de Derecho", ideario que, sin solución de continuidad conceptual, se precisa al decir del pasaje 9.2, cuya literalidad, recordemos, es la siguiente: "corresponde a los poderes públicos promover las condiciones para que la libertad e igualdad del individuo y de los grupos que en que se integra sean reales y efectivas; remover los obstáculos que impidan y dificulten su plenitud(...)". El discurso que se deriva de tales pasajes, lo podríamos juridificar procesalmente y subirlo de tono todavía más, añadiendo la cita de aquel otro pasaje del mismo texto en el que se reconoce, con rango de fundamental, el derecho subjetivo que otorga a los individuos a que puedan "obtener la tutela efectiva de los jueces y tribunales(...) sin que en ningún caso pueda producirse indefensión” (art. $24 \mathrm{CE}$ ); derecho del cual ya queremos presentar dos primeras referencias: que tiene

19 CALAMANDREI, P. Proceso y Democracia. Lima: Ara Editores E.I.R.L, 2006, pág. 134.

20 RODRÍGUEZ-PIÑERO Y BRAVO-FERRER; M. Proceso de trabajo y justicia constitucional, En: AA.VV. E1 proceso laboral. Estudios en Homenaje al Profesor Luis Enrique de la Villa Gil. Valladolid: Lex Nova, 2001, págs. 723 a 776. 
un contenido complejo que agrupa... una serie de derechos simples que, o bien forman parte del mismo o bien sirven de complemento a su efectividad: derecho de acceso a la prestación jurisdiccional, derechos a obtener una resolución fundada... garantía de los medios de prueba pertinentes para la defensa... etc. ${ }^{21}$

y que, de tal complejo contenido forman parte las manifestaciones del principio de igualdad. $^{22}$

Este escenario político constitucional en el que todos los poderes públicos están obligados no sólo a "promover" sino también a "remover" obstáculos en pro de la "libertad" e "igualdad" "reales y efectivas" y para garantizar "en todo caso" la "tutela judicial efectiva", exige que las instituciones y categorías jurídico-procesales estén configuradas y ordenadas de manera que el poder judicial pueda ejercer sus funciones de acuerdo con tales requerimientos constitucionales: el texto constitucional representó el inicio de una nueva etapa política y el de una novedosa concepción de la justicia efectiva basada en una igualdad tan integral como real, nuevos planteamientos todos, que sin duda, debían ser más evidentes e intensos en el ámbito competencial del orden social de la jurisdicción por cuanto que en el mismo no se dirimen cualquier tipo de conflictos, sino sólo los sociales, pero además porque las partes de estos litigios son singulares por la marcada desigualdad social, jurídica y económica que existe entre las mismas. ${ }^{23}$ Este nuevo sentido del valor supremo de la justicia auspiciado por el texto constitucional se disciplinó por la Ley Orgánica 6/1985, de 1 de julio, del Poder Judicial, ${ }^{24}$ de cuya Exposición de Motivos ya se desprende que el poder judicial está obligado a promover las condiciones para que la libertad y la igualdad del individuo y de los grupos sean "reales y efectivas", $25 \mathrm{y}$ en cuyo articulado se preceptúa alguna que otra idea ya avanzada por nuestra parte, tales como que

La Constitución es la norma suprema del ordenamiento jurídico, y vincula a todos los Jueces y Tribunales, quienes interpretarán y aplicarán las Leyes y los Reglamentos según los preceptos y principios constitucionales, conforme a la interpretación de los mismos que resulte de las resoluciones dictadas por el Tribunal Constitucional en todo tipo de procesos (art. 5.1). ${ }^{26}$

${ }_{21}$ PÉREZ AMORÓS, F.; ROJO, E. y SAURA, L.: Formularios procesales laborales. Comentarios y jurisprudencia. 2. ed. Barcelona: Bosch, Casa Editorial, 1991, pág. 69.

22 STC 226/1988, de 28 de noviembre (BOE, 22 diciembre; corr. err. BOE, 23 diciembre), especialmente Fundamento Jurídico 3, segundo párrafo.

23 CRUZ VILLALÓN, J. Constitución y proceso de trabajo, en: “CRUZ, J. y VALDÉS, F. Lecturas sobre la reforma del proceso laboral. Madrid: Ministerio de Justicia, 1991, págs. 9 a 85. (Idem, en: Revista española de Derecho del Trabajo, núm. 38/1989).

24 BOE de 2 de julio; corr. err. BOE de 4 de noviembre.

25 Punto III, penúltimo párrafo de tal Exposición de Motivos.

26 VALDÉS DAL-RÉ, F.: El nuevo proceso laboral. Relaciones Laborales, núm. 14/1990.; 
Y, como textos de legislación ordinaria básicos a nuestros efectos hemos de señalar, en muy apretada síntesis, los que siguen. La norma de ritual por excelencia es el vigente Texto Refundido de la Ley de Procedimiento Laboral aprobado por el Real Decreto Legislativo 2/1995, de 7 de abril ${ }^{27}$ (en adelante, TRLPL), fuente que ya hemos citado e identificado y de la que ofreceremos variados detalles particulares cuando mejor convenga.

Por expreso mandato del citado TRLPL (Disposición Adicional Primera, punto 1), en lo no previsto en la misma regirá como supletoria la Ley $1 / 2000$, de 7 de enero, de Enjuiciamiento Civil (BOE de 8 de enero; corr. err. BOE de 14 de abril), previsión que si bien en puridad no nos merece reparo, sí que nos suscita una reflexión, cual es que, en nuestra opinión, tal remisión debe entenderse hecha con la prudencia - o "moderadamente", en expresión judicial; 28 "limitado", para la doctrina científica ${ }^{29}$ - debida, y, de forma especial, muy ponderada en materia probatoria ${ }^{30}$ pues conocidas son de antemano las claras diferencias que existen entre el simétrico proceso civil y el asimétrico proceso laboral o social, queriendo sugerir con ello que a la consabida autonomía del Derecho del Trabajo del ordenamiento común debe seguir, y por las mismas razones y con idéntico énfasis, la autonomía del Derecho

idem En: "CRUZ, J. y VALDÉS, F. Lecturas sobre la reforma del proceso laboral. Madrid: Ministerio de Justicia, 1991, págs. 323 a 352.

27 BOE de 11 de abril; corr. err. BOE de 26 de mayo. Este texto refunde las disposiciones dictadas desde la publicación del anterior texto articulado de Ley de Procedimiento Laboral aprobado por el Real Decreto Legislativo 52/1990, de 27 de abril (BOE de 2 de mayo), que traía a su vez origen de la Disposición adicional duodécima de la precitada Ley 6/1985 del Poder Judicial, y de la Ley de 7/1989, de 12 de abril de bases del Procedimiento Laboral (BOE de 13 de abril). Es así pues, que el vigente TRLPL ya se había adaptado a los preceptos de la CE de 1978 con anterioridad a la fecha de vigencia del mismo. Adviértase pues, como con ocasión de la aprobación de la LPL de 1990 ya había dado comienzo la adecuación de las normas procesales laborales básicas a las nuevas exigencias dimanante de al CE de 1978, al respecto vid. por todos la poligrafía: ALARCÓN, MR (Coord.): Estudios sobre la Ley de Procedimiento Laboral de 1990. Madrid: Marcial Pons, 1991; la aportación de MONTOYA MELGAR, A.: El proceso laboral y sus reformas en España, En: El Derecho del Trabajo en los albores del siglo XXI. Memorias y Comunicaciones del $<<$ Congreso Internacional del Derecho del Trabajo $>>$. Isla Margarita. Venezuela Abril-Mayo de 2007.Revista Derecho del Trabajo; núm. 3 (extraordinario) de 2007; y más in extenso, Comentarios a las Leyes Laborales. La nueva Ley de Procedimiento Laboral (Real Decreto Legislativo 521/1990, de 27 de abril), dirigidos por EFRÉN BORRAJO DACRUZ. Madrid: Editorial de Derecho Reunidas, 1990.

28 En la - temprana por preconstitucional - Sentencia del Tribunal Supremo de 29 de enero de 1977 (Ar. 1348).

29 CRUZ VILLALÓN, J. El limitado alcance de la supletoriedad de la Ley de Enjuiciamiento Civil de 2000 en el proceso laboral, en: MARTÍNEZ ABASCAL, VA. (Coord.): Nueva Ley de Enjuiciamiento Civil y Proceso Laboral . Madrid: Marcial Pons, 2002.

30 JUANES FR AGA, E. La prueba en el proceso de trabajo: novedades de la Ley de Enjuiciamiento Civil, en: "AA.VV.: El proceso laboral. Estudios en homenaje al Profesor Luis Enrique de la Villa Gil . Valladolid: Lex Nova., 2001, especialmente, en su punto "I Introducción”, págs. 379 a 382 . 
Procesal Laboral del Derecho Procesal Civil, opinión esta que anteriormente ya hemos pergeñado al apuntar que más que referirnos al Derecho Procesal del Trabajo convendría hacerlo del Derecho del Trabajo Procesal. No resulta necesario recurrir a cita alguna para convenir que una de las causas que explica el nacimiento del Derecho del Trabajo debe buscarse en la falta de adaptación del ordenamiento civil o común para regular las nuevas relaciones laborales que surgieron a partir de ciertos momentos; pero si conviene formular el correlato del anterior recordatorio al amparo de la mejor doctrina que afirma que el proceso laboral "es directa consecuencia de la inadaptación del proceso civil para resolver adecuadamente los litigios de trabajo". ${ }^{31}$ De lo dicho, y sin más polémica, podríamos argumentar a favor de la autonomía del proceso laboral del proceso civil, no sin tener presente que la institución del proceso bien puede entenderse como única en si misma considera; distanciamiento que no debe ocultar que, con el paso del tiempo, algunas de las propuestas que primero se hicieron para dotar de personalidad al proceso laboral se han recuperado en parte después para actualizar el proceso civil, dando lugar a un fenómeno pendular que entre nosotros se conoce como "fenómeno de inversión histórica," 32 hecho que si citamos no es para profundizar en el mismo sino para poner de relieve lo dinámico la cuestión y la consiguiente virtualidad teórica y práctica del fondo de de la misma. (Dicho sea entre paréntesis: ¿Qué norma procesal, fue la que se adaptó primero en el tiempo al nuevo planteamiento de la Constitución de 1978, la civil o la laboral?).

\section{Princípios inspiradores del proceso laboral}

7. El proceso, es una institución jurídico pública creada para vehicular la potestad jurisdiccional - juzgando y ejecutando lo juzgado - que posibilita que un tercero, especialmente (pre)instituido al efecto, componga o dirima con imparcialidad, rapidez y certeza el conflicto que las partes formalizan en un plano de igualdad, y que tiene como objetivo garantizar (restituir) el ejercicio real y efectivo del derecho menoscabado previo esclarecimiento de los hechos. Su naturaleza "pública", la "rapidez" y "certeza" en la actuación del órgano jurisdiccional, el que las partes en conflicto actúen en un plano de "igualdad", y el que la finalidad última

31 RODRÍGUEZ-PIÑERO, M.: Sobre los principios informadores de del proceso de trabajo. Revista de Política Social, núm. 81/1969, pág. 22, punto 1 in prius. ; idem: Los principios informadores del proceso de trabajo. En: GUZMÁN, HB (ed. a cargo de): Derecho Procesal del Trabajo. Republica Dominicana: Editora Dalis. Moca, 2002, págs. 69 a 104.

32 RUSSOMAnO, MV.: Decálogo del Proceso Laboral. Presentación de un autor y su obra, por SERRANO CARVAJAL, J. Madrid: Universidad Complutense. Facultad de Derecho. Sección de Publicaciones. Madrid, 1986, pág. 56. 
de todo ello sea prevenir el derecho lesionado de forma "real y efectiva", son sin duda las notas conceptuales básicas configuradoras del proceso laboral: el proceso laboral no es en si mismo un derecho, es un "un instrumento de aplicación del Derecho del Trabajo" ${ }^{\prime 33}$ para hacer posible que los derechos materiales laborales puedan ejercitarse real y efectivamente, resultando así ser el soporte del derecho a la tutela judicial efectiva. Y así las cosas, podemos concluir este punto aseverando que no hay (o no debe haber) - sino todo lo contrario - disfunción funcional alguna entre las normas sustantivas laborales y las de ritual de idéntica condición.

Como bien se ha escrito, "cabe un procedimiento sin proceso (legislativo, administrativo, etc.) pero no proceso sin procedimiento" 34 , queriendo con ello dejar constancia de que, siendo cierto que debemos diferenciar entre uno y otro, también lo es, y no menos, que en entre ambos conceptos existe una estrecha relación, pues la ordenación del segundo trae su razón de ser de la función del primero, y en consecuencia, no resulta fácil distinguir los principios que inspiran el proceso de los criterios que hacen lo propio con el procedimiento, pero deviene pacífico afirmar que éste (cual cuerpo) está al servicio de aquél (cual alma).

8. A continuación trataremos de caracterizar el proceso laboral a partir, esencialmente, de su función tuitiva, y así lo haremos con la evocación de los principios que lo informan, manteniendo así el tono general de estas nuestras consideraciones y el orden previsto.

Pero antes de glosar tales principios, primero recordaremos una cita legal ya mencionada con la seguridad de que en esta segunda ocasión su contenido resultará más ilustrativo si cabe, y en segundo lugar añadiremos una cita doctrinal, muy conocida entre los estudiosos del tema, para que con tal doble marco nuestro comentario sobre los antedichos principios pueda ser breve y, si es posible, aleccionador.

Vayamos pues con la cita legal. El TRLPL, recordemos, preceptúa que los "órganos judiciales" deberán corregir "los actos que, al amparo del texto de una norma, persigan un resultado contrario al previsto en la Constitución y en las leyes para el equilibrio procesal, la tutela judicial y la efectividad de las resoluciones," 35 mandato que, partiendo del debido respeto a un texto constitucional como el comentado, persigue una tutela judicial fundada en el "equilibrio" procesal - igualdad, decimos nosotros entre los sujetos procesales - y la "efectividad" de lo juzgado. Precepto,

33 GARCÍA FERNÁNDEZ, M.: Tutela jurisdiccional y carga de la prueba en el proceso de trabajo. Revista española de Derecho del Trabajo, núm. 15/1983, pág. 383.

34 LUELMO MILLÁN, MA. ;y RABANAL CARBAJO, P. Los principios inspiradores del proceso laboral. Madrid: McGraw-Hill, 1999, pág. 4.

35 Art. 75.1. 
entre otros varios que podríamos evocar, que si lo reconducimos en concreto al ámbito del proceso laboral, no puede ser mejor interpretado que trayendo a colación la siguiente afirmación doctrinal: el juzgador laboral tiene la "necesidad de operar para que la igualdad de las partes en el proceso no fuese solamente formal, sino sustancial y efectiva, lo que no era posible sino consintiendo al juez el venir en ayuda de la parte socialmente más débil..."; 36 a lo que el propio autor añade que tal auxilio en favor de la parte procesal débil resulta ser más necesaria "en el terreno probatorio", añadido que sin duda tiene interés para nosotros, pues permite configurar mejor el proceso laboral, y además nos resulta útil para cohesionar mejor el orden que seguimos en nuestra Ponencia, pues como hemos explicitado, en la última parte de la misma nos referiremos a cómo la propuesta, admisión, práctica y valoración de las pruebas se gestionan y efectúan de tal manera que las partes procesales puedan desenvolverse en un plano de igualdad real evitando así cualquier posible manifestación de indefensión alguna que pudiera minusvalorar la justicia efectiva. ${ }^{37}$

Llegados a este punto, no parece equivocado afirmar que entre todos los posibles principios que inspiran el proceso laboral - que es y debe ser siempre un proceso "con todas las garantías", 38 dos de los de mayor relieve son: la igualdad de las partes procesales y la rapidez del mismo, citados sean, precisamente, en este orden. Ambos nos merecen tan alta consideración jurídica por cuanto que aseguran que el proceso garantice el derecho de tula judicial cual su efectividad real, dicho sea todo ello en los términos que pasamos a presentar; y es por ello que también se podría convenir que tales principios no son más que la concretización del principio tutelar inspirador del Derecho Procesal Laboral con ocasión de tratar de una de sus instituciones básicas como lo es el proceso laboral. La igualdad de las partes y la rapidez procesal son principios propios del proceso en general, y en consecuencia inspiran -cada vez más- el proceso civil, pero en el proceso laboral tienen un calado tan especial que les confiere un sentido propio: si admitimos que el conflicto propio del proceso civil (simétrico) es distinto del laboral (asimétrico), deberemos postular que ambos procesos no se identifican totalmente, y en consecuencia que los principios inspiradores de ambos son y deben ser dispares.

\footnotetext{
36 RODRÍGUEZ-PIÑERO, M. Sobre los principios informativos del proceso de trabajo. Revista de Política Social, núm. 81/1969, pág. 81.

37 SEGALÉS, J. La prueba en el proceso laboral. Tras la Ley 1/2000 de Enjuiciamiento civil.: Granada: Comares. 2002.

38 Art. 24.2 CE.
} 
9. Tratar del principio de igualdad de las partes en el proceso laboral, requiere hacerlo con rotundidad pues a ello nos obliga el haber elegido la afirmación de autor que encabeza estas páginas, y haber afirmado supra que, sustancialmente, lo que diferencia la izquierda de la derecha es la defensa de la igualdad de las personas.

La igualdad procesal consiste en un trato procesal desigual de las partes desiguales otorgando un plus de protección a la parte trabajadora: ${ }^{39}$ "Se trata de excepcionar desigualatoriamente reglas procesales de carácter general". ${ }^{40}$ Siendo cierto que "La proclamación del derecho al igual disfrute de los derechos y libertades fundamentales nació un tanto desligada de las injusticias económico sociales, ignoraba los abusos del derecho de propiedad, no afectó a la explotación del trabajo ajeno...” ${ }^{\prime 1}$; resulta necesario que

la concepción del derecho del trabajo, también del derecho procesal del trabajo, como ordenamiento compensador e igualador de desigualdades materiales o reales, no sólo permite, sino que también demanda... el establecimiento de tratamientos procesales diferenciados en beneficio del trabajador. ${ }^{42}$

Sobre una igualdad procesal de tal condición y naturaleza debemos formular una primera precisión, de la que, a su vez, deduciremos otras consideraciones, siendo todas ellas algo más que simples matices del debate que nos ocupa.

La igualdad de las partes debe ser real y no sólo formal, pues en caso contrario el proceso no cumpliría con el objetivo final que está llamado a alcanzar, cual es que el titular del derecho vilipendiado - en opinión del órgano juzgador- pueda ser ejercido por su titular de forma real y efectiva. Por lo demás, la desigualdad compensatoria procesal, si es debidamente ponderada, para nada, desdice lo contradictorio del proceso ni empaña la imparcialidad propia y lógica de quien falla y dicta sentencia. ${ }^{43}$ Es más, perseguir la igualdad real (igualdad en los resultados) mediante la desigualdad formal de las partes procesales (desigualdad en los medios), es un proceder compensatorio muy aceptable en cuanto que está justificado por razones objetivas

39 Recordar la citada Sentencia del Pleno del Tribunal Constitucional 3/1983, de 25 de enero.

40 ALARCÓN CARACUEL, MR. Una valoración crítica global de la Ley de Bases de Procedimiento Laboral, En: “ALARCÓN, MR. (Director): La reforma del Procedimiento Laboral. Madrid: Marcial Pons. 1989, pág. 20.

41 MUÑOZ CAMPOS, J. El principio de igualdad en el proceso laboral, En: Jornadas sobre cuestiones actuales de enjuiciamiento laboral. Madrid: Instituto de Estudios Laborales y de la Seguridad Social. Ministerio de Trabajo y de la Seguridad Social, 1985, pág. 365.

42 CASAS BAAMONDE, ME. La reforma de la legislación procesal laboral: los recursos en la Ley de Procedimiento Laboral. Revista española de Derecho del Trabajo, 46/1991, 197.

43 Sobre el requerimiento de imparcialidad de todos y cada unos de los órganos jurisdiccionales que integran el poder judicial, ver art. $117 \mathrm{CE}$. 
cuando no exigido por un Estado Social que parte de la existencia de desigualdades entre trabajadores y empresarios y entre las correspondientes clases sociales, y que por ello postula, en los términos constitucionales comentados, que tales desequilibrios individuales y colectivos deben superarse. ${ }^{44} \mathrm{La}$ conocida expresión "equiparación de armas" que tanto utilizamos - Tribunal Constitucional incluido- para hacer más gráfica la función tutelar de las normas laborales, sustantivas y procesales, es una operación que consiste en desigualar los medios desiguales para igualar los resultados: en nada pues se desdice la igualdad real de los justiciables.

Y en la misma línea discursiva, cabe añadir que si postulamos que la igualdad procesal ha de ser real y no simplemente formal, también hemos de patrocinar que la verdad que debe buscar quien juzga no es la formal sino la material u objetiva, porque si no fuera así el derecho menoscabado, una vez repuesto judicialmente, no podría volver a ejercitarse real y efectivamente. Entendemos que el binomio igualdad formal-verdad formal, debe someterse a la sana crítica y sustituirse por otro que interrelacione la igualdad real con la verdad material, y lo haga de tal manera que ponga de relieve que entre ambas expresiones algebraicas existe una cuasi relación de causaefecto. Nuestro más alto Tribunal, ya en el año 1984, sentenció que "la búsqueda de la verdad material, es, como afirma la doctrina, el objetivo central del proceso laboral" ${ }^{\prime 4}$, planteamiento que tiene mayor consideración si recordamos que en reiteradas ocasiones el mismo Tribunal se ha pronunciado en favor de que las manifestaciones del principio de igualdad procesal tienen amparo en el repetido artículo 24 del texto constitucional en el que se da cabida al derecho de tutela judicial efectiva. ${ }^{46}$

Y para finiquitar con la ejemplificación de algunas de las muchas sugerencias que nos despierta el principio de igualdad formal en el sentido que lo entendemos, hemos de referirnos a la gratuidad del proceso laboral (beneficio de justicia gratuita) preceptuada con base constitucional ${ }^{47}$, pues es un irrefutable reconocimiento legal de que el legislador, tras admitir que entre las partes litigantes existen desequilibrios - económicos, en este caso: por dependencia salarial, dicho sea apocopadamente

$\overline{44}$ BAYLOS, A. La igualdad de las partes en el proceso laboral y la tutela judicial efectiva. Derecho Privado y Constitución, 4/1994, págs. 107 a 129. Vid, también del mismo autor, su Prólogo a la obra, "SÁVIO ZAINAGHI, D. A soluçao extrajudicial dos conflitos trabalhistas no Brasil. São Paulo: LTR, 2004, págs. 11 a 17.

45 Sentencia del Tribunal Constitucional (STC, en adelante) 62/1984, de 21 de mayo, de la Sala Primera (BOE 19 junio, cor. err, BOE, 11 junio), en su FJ, Tercero.

46 Por todas, STC 226/1988, de 28 de noviembre (BOE 22 diciembre; corr. er. BOE 23 diciembre), en su Fundamento Jurídico 3, segundo párrafo.

47 Partiendo del artículo 24.1 CE, citado y glosado, ver art. 20 LOPJ, citada, y en especial, ver. art. 2.d de la Ley 1/1996, de 10 de enero, de asistencia jurídica gratuita (BOE, 12 de enero). 
-, otorga a la partes un trato económico desigual favorable (gratuidad), a la parte procesal débil, para, precisamente igualarlas, evitando, en una ocasión más, la posible indefensión de la misma. ${ }^{48}$

12. En punto al principio de rapidez digamos lo siguiente. Si por designio constitucional la justicia ha de ser efectiva, no cabe duda alguna que la justicia ha de ser rápida: por mucha igualdad que exista entre las partes en conflicto, "una justicia lenta no es justicia" - dicho sea en frase de 1887 atribuida al insigne cubano José Martí -, pues la tardanza impide que, de manera real se ejercite el derecho que se reponga en sentencia. Y por lo demás - y no es poco -, la lentitud de la justicia es un despilfarro de dinero público. Obviamos aquí el detalle de la polémica en torno a si la rapidez alcanza, por si mismo, la condición de auténtico principio inspirador del proceso - así nos lo parece a nosotros - o bien sólo es una mera proyección concreta del genérico principio tuitivo del ordenamiento, pero sí queremos dejar constancia que la propia CE postula, de forma expresa, un "proceso(...) sin dilaciones", ${ }^{49}$ rapidez que relaciona estrechamente con la efectividad de la justicia pues ambas exigencias se incluyen en un mismo pasaje constitucional, y no precisamente en uno cualquiera, sino en el que se establece, ni más ni menos, que el derecho subjetivo a la tutela judicial efectiva a favor de todos: ${ }^{50}$ es por ello que nuestro Tribunal Constitucional se refiere al "derecho a un proceso rápido". 51

Pero es más, la justicia efectiva y real ha de ser algo más que rápida, ha de ser segura por imperio del "principio de veracidad, que debe regir en materia de laboral" 52 , doble exigencia de todo proceso laboral que entendemos tiene mayor proyección en la fase probatoria del procedimiento laboral.

$\overline{48}$ Una lectura detenida del artículo 21 del TRLPL - debidamente complementada con la Disposición adicional quinta de la precitada Ley 171996, de 10 de enero, de asistencia jurídica gratuita, de la que trae causa el mismo - da prueba de cómo el legislador procesal persigue "la igualad de las partes" (art. 21.3 TRLPL) mediante una particularizada justicia gratuita en el orden social de la jurisdicción.

49 Art. 24.3 CE.

$50 \quad$ En el repetido 24 de la CE.

51 En su sentencia 99/1998, de 4 de mayo.

52 HERRERA CARBUCCIA, MR. La sentencia, En: "HERRERA CARBUCCIA, MR. (Coord): Estudios de procedimiento laboral en Iberoamerica Republica Dominicana: Asociación Iberoamericana de Derecho del Trabajo y Librería Jurídica Internacional. República Dominicana, 2007, pág. 618. 
13. Ambos principios del proceso laboral tienen su entronque y justificación en la CE - en concreto: "son manifestaciones del principio constitucional de tutela judicial efectiva" 53 -, idea que desde principio hemos venido apuntado y que ahora recuperamos y ampliamos.

Como hemos expresado, la igualdad real de las partes del proceso y la rapidez procesal tienen su entronque constitucional en el propio Título Preliminar de dicho texto; y a su vez, tales principios constituyen la raíz y guía de los criterios y reglas que disciplinan el procedimiento laboral y los que nos referiremos infra. De lo prevenido en los citados pasajes 1.1 y 9.2 de la CE, interesa reiterar aquí que: los poderes públicos - el judicial incluido - deben "establecer las condiciones para que la libertad y la igualad del individuo - sujetos procesales incluidos- sean reales y eficaces" ${ }^{254}$; y, especialmente, por lo de impulso público que conlleva, que tales poderes deben en imperativo - "remover los obstáculos que impidan o dificulten su plenitud (la del ejercicio real y efectivo de la libertad e igualdad)(...)" ${ }^{55}$ Es en este escenario constitucional en el que debe entrar en liza el mandato prevenido en el ordinal 24.1 del mismo texto y de cuyo tenor literal cabe significar lo siguiente: atribuye a "todas las personas" el derecho subjetivo a una "tutela judicial efectiva" y le otorga el rango de derecho constitucional fundamental, precisando que en virtud del mismo, y "en ningún caso" se podrán "producirse indefensión”, quedando así configurado lo que podríamos denominar el núcleo de la delimitación del derecho en cuestión, planeamiento que se complementa con los aportes contenidos en otro punto del mismo artículo constitucional en el que se previene que, asimismo, todos tienen derecho a un proceso "público" que se desarrolle "sin dilaciones" y "con todas las garantías" y a utilizar "los medios de prueba pertinentes" para su defensa (art. 24.2, 1er. párrafo de la CE). ${ }^{56}$

Significado lo cual resultan sobreros otros aportes para poder concluir este punto afirmando que los principios de igualdad y rapidez procesal dan buena cuenta del acertado significado del derecho a una tutela judicial efectiva; y así las cosas, sólo nos quedaría cerrar este punto reiterando una idea utilizando, en este caso, el decir de solvente doctrina:

53 ALARCÓN CARACUEL, MR. Una valoración crítica global de la Ley de Bases de Procedimiento Laboral, En: “ALARCÓN CARACUEL, MR. La reforma del procedimiento Laboral. Madrid: Marcial Pons., 1989, pág. 19.

54 Citado art. 9.2 CE, en la primera parte del concepto que contempla.

55 Art. 9.2 CE, en el segunda parte del mandato de referencia.

56 SAÉZ LARA, C. La tutela judicial efectiva y el proceso laboral. Madrid: Thomson-Civitas. 2004. 
Un Estado social y democrático de Derecho, obligado a promover la igualdad real y efectiva (art. 9.2 CE), no sólo tiene que facilitar el acceso a la jurisdicción a quien por su situación desigualdad económica y jurídica puede tener -y tiene de hecho- dificultades para ello, sino que tiene que tener en cuenta que aquella desigualdad puede pervivir y manifestarse en el transcurso del proceso. ${ }^{57}$

14. En la misma línea argumental, y partiendo de la misma base constitucional, podemos anticipar que, como detallaremos en un apartado siguiente, los principios inspiradores del proceso, a su vez, dan origen y sustento a los criterios que aseguran que las sucesivas fases del procedimiento se suceden en el tiempo con orden y prontitud - incluso en ocasiones con la urgencia y preferencia propia del caso -, impidiendo cualquier maniobra de filibusterismo procesal que se intentara poner en práctica al amparo - torticero - de un formalismo enervante ts $^{58}$ pero que en realidad constituyera un fraude legal o, incluso, un abuso de derecho: la chicana ya estaba repudiada en las Leyes 4 y 8 , Titulo 22, Libro V, de la Novísima Recopilación. ${ }^{59}$

Tales criterios del procedimiento conllevan mayor igualdad y rapidez procesal cuando se trata de regir, en concreto, la fase probatoria, y en este sentido, comprobaremos como algunas de las técnicas procesales previstas al respecto -v. gr, sobre la inversión de la carga de la prueba- no son más que remociones de obstáculos por parte de los poderes públicos con la finalidad de que el conflicto se pueda dirimir con una igualdad de armas y en un tiempo razonable, y en definitiva, para que siendo posible conocer la verdad real, la tutela judicial resulte ser realmente efectiva.

15. Al hilo de lo comentado sobre el principio de igualdad de las partes, se nos va a permitir, sin mayor contextualización, recordar que los sindicatos y las asociaciones empresariales tienen reconocida legitimación para la defensa de los “intereses” económicos y sociales que le son propios (art. 17.2 TRLPL: ${ }^{60}$ tutela judicial de intereses colectivos) todo

57 GARCÍA-PERROTE ESCARTÍN, I. La prueba en el proceso de trabajo. Madrid: Civitas. 1994, pág. 94.

58 RODRÍGUEZ-PIÑERO, M. Jurisdicción de trabajo y sistema constitucional, en: ALARCÓN CARACUEL, MR. La reforma del procedimiento Laboral. Madrid: Marcial Pons. 1989, págs 45 y ss., al tratar de la "restricción del formalismo <<enervante $>>$ ".

59 OSSORIO y GALLARDO, A. El alma de la toga. Buenos Aires: Valleta Ediciones, Argentina, págs. 70 a 91.

60 La literalidad de este pasaje nos merece dos menciones puntuales: la primera para señalar que su terminología es muy pareja a la que utiliza la CE con ocasión de tratar de la función de los sindicatos en un Estado Social (art. 7 CE) y de libertad sindical (art. 28 CE); y la segunda, para significar que el legislador procesal no utiliza la expresión "derechos", sino "intereses". Las limitaciones de espacio que nos condiciona, impide otro comentario que no sea dejar apuntado que 
ello al amparo de la CE, ${ }^{61}$ y que los sindicatos pueden actuar en un procedimiento en nombre e interés de los trabajadores afiliados a los mismos (art. 20.1 TRLPL: tutela judicial de intereses individuales), para poder añadir a continuación que tales previsiones procesales en favor del sindicato no sólo son manifestaciones del principio de igualdad real de las partes procesales en favor del trabajador, sino también prácticas que pretenden la igualdad entre los grupos o clases sociales, todo ello al amparo de los mandatos constitucionales ya citados y glosados que pergeñan nuestro Estado Social. Este planteamiento puede completarse añadiendo que los sindicatos tienen reconocida legitimación para intervenir en la modalidad procesal de conflictos colectivos y de impugnación de convenios colectivos, entre otras cuya cita obviamos (arts. 152 y 162 - y concordantes de ambos - del TRLPL). ${ }^{62}$ Todo ello nos permite concluir apuntando que: siendo la libertad sindical en si mismo considerada uno de los paradigmas de la función tuitiva del Derecho del Trabajo, también resulta lógico que tal derecho de derechos tenga protagonismo tutelar en estrados pues es un escenario en el cual, los actores-trabajadores y los demandados-empresarios también actúan en un plano de desigualdad; relevante intervención procesal de los sindicatos de la que cabe enfatizar que no sólo comporta la defensa de derechos laborales individuales, sino también la de intereses y derechos colectivos. ${ }^{63}$

La idea que queremos transmitir con lo comentado en este punto, se explica mejor si tenemos presente que tal sindicalización del proceso laboral fue una de las principales aportaciones de la postconstitucional Ley de Procedimiento Laboral de 1990 (ex. art. 17.2) - antecedente directo del vigente TRLPL de 1995 -, pues tal novedad pone de relieve como la norma básica del Derecho Procesal Laboral vigente en el momento se ajustó, en tiempo y forma, al ideario de una Constitución (de 1978) que entre sus logros más significados se cuenta con el del pleno reconocimiento de la libertad sindical (arts. 7 y 18): así pues el ajuste político-procesal está

ambas menciones resultan ser muy expresivas en punto a lo que comentamos en este punto de nuestra exposición.

${ }_{61}$ Ver STC 210/1994 de 11 de julio (BOE de 4 de agosto) y 17/2002 de 30 de septiembre (BOE de 24 de octubre)

62 PALOMEQUE, C.: Sindicato y proceso de trabajo. Revista de Política Social, núm 122/1979; y, MURCIA CLAVERÍA, A. La representación voluntaria en el proceso laboral. Madrid: Marcial Pons, 1994.

${ }_{63}$ CRUZ VILLALÓN, J. La intervención de las representaciones colectivas en el proceso de trabajo, en: "VALDÉS DAL-RÈ, F. Lecturas sobre la reforma del proceso laboral. Madrid: Ministerio de Justicia. 1991; y, ORTIZ LALLANA, mc.: La intervención del sindicato en el proceso de trabajo. Madrid: CES. Madrid, 1994. 
servido; tenían pues plena razón los comentaristas de la LPL de 1990 que ante una norma que concedía tal nuevo papel procesal del sindicato ya advirtieron que "No creemos contenga una mera norma neutra o de valor simplemente retórico". ${ }^{64}$

Ya lo hemos defendido en otras ocasiones, en ningún texto está escrito que el intervencionismo definidor de un Estado social - que "con un trato jurídicamente diferenciado que permita asegurar la igualdad real entre los hombres" ${ }^{\prime 65}$ - deba tener como único actor al propio Estado en sentido estricto, y mucho menos que así sea si nos referimos al intervencionismo social; ${ }^{66}$ en cambio merece nuestra aprobación sostener que la democracia real y avanzada debe ser también una democracia pluralista que otorgue al sindicato funciones propias de un auténtico agente social político y económico - pues "la participación social abarca, en realidad, un ámbito más amplio, que incluye no sólo los aspectos sociales, sino también... políticos, económicos y culturales" ${ }^{67}$ En este contexto general, entendemos que entre tales manifestaciones de sindicalismo cabe incluir que los sindicatos pueden intervenir desde primera línea en dirimir conflictos sociales sea cual sea el lugar (judicial y extrajudicial) donde se pretenda hacerlo.

Y quizás sea bueno dejar - sólo - apuntado aquí, que en unos momentos de crisis económica como en los actuales, de la misma manera que postulamos que el sindicalismo debe forzosamente asumir nuevos retos, también debemos adelantar que somos de la opinión que el sindicato debe avanzar fortaleciendo todavía más la defensa de los intereses colectivos de todos los que trabajan (ocupados o no) sin que ello comporte abandonar la defensa de los derechos de los trabajadores: es una manera como otra de dar estabilidad al pacto político suscrito entre el mercado y el Estado social al que nos hemos referido e intentar así superar la crisis con la ponderación debida.

\footnotetext{
64 MARTín VALVERDE, A. La Parte General de la Ley de Procedimiento Laboral de 1990, en, "ALARCÓN, MR. (Coord.): Estudios sobre la Ley de Procedimiento Laboral de 1990. Madrid: Marcial Pons, 1991, pág. 17.

65 RUIZ MORENO, AG: Nuevo Derecho de la Seguridad Social. México: Edit. Porrúa. 2003 (Séptima edición), pág. 5.

${ }_{6}$ PÉREZ AMORÓS, F. El intervencionismo estatal y el Derecho del Trabajo: la Inspección de Trabajo y Seguridad Social. En : ESPUNY TOMÁS, MJ. y PAZ TORRES, O. (Coords.): La Inspección de Trabajo 1906-2006. Valencia: Tirant lo Blanch, 2008, págs. 11 a 38.

67 YSAS MOLINERO, H. La participación de los sindicatos en las funciones normativas de los poderes públicos. Una comparación entre España y Francia. Tesis Doctoral. Barcelona: Universidad Autónoma de Barcelona, febrero 2009, pág. 195 (consulto original inédito; en prensa).
} 


\section{Los criterios ordenadores del procedimiento laboral}

16. Los distintos actos que conforman cada una de las fases que se suceden o transcurren en el tiempo para tramitar el proceso laboral están regulados por las normas procesales, y todo ello da cuerpo a lo que venimos denominando el procedimiento laboral como categoría jurídica. Así pues, el procedimiento es el conjunto de "normas reguladoras del proceso" o "la tramitación del proceso" dicho sea apocopadamente pero en dicción legal que después ubicaremos en el TRLPL; o el procedimiento es una "secuencia de actos que se encadena ordenadamente", dicho sea ahora al amparo de la doctrina científica. ${ }^{6}$ En todo caso, el procedimiento está al servicio del proceso, y por ello los principios y el fin de este condicionan el sentido de aquél.

17.El Título VI - último del Libro Primero del TRLPL -, rubricado "De los principios del proceso y de los deberes procesales", comprende los artículos, el $74^{69}$ y el $75::^{70}$ pocos ordinales pues para tratar de tan importante cuestión, y ordinales que sin duda están redactados con técnica jurídico dogmática susceptiblemente mejorable; pero artículos que podemos considerarlos suficientes si tenemos en cuenta, tanto su literalidad como sistemática y ubicación en el texto. Al contenido de ambos pasajes nos referiremos infra, pero aquí y ahora ya queremos subrayar que dedicar al tema que nos ocupa un exclusivo Título propio, Título que por lo demás cierra el Libro Primero ("Parte general"), no es más que un recurso de técnica legislativa utilizado por el legislador para magnificar y solemnizar el significo de los preceptos recogidos en tales ordinales; es más, debemos significar que la rúbrica del Título VI citado no sólo se refiere a los "principios procesales" ordenadores del procedimiento, sino también y de forma seguida a los "deberes procesales",

$\overline{68}$ BAYLOS GRAU, A.; CRUZ VILLALÓN, J.; FERNÁDEZ, MF. Instituciones de Derecho Procesal Laboral. Madrid: Trotta. 1995, pág. 73.

69 Para su general conociendo reproducimos su literalidad: "1.Los Jueces y Tribunales del orden jurisdiccional social interpretarán y aplicarán las normas reguladoras del proceso laboral ordinario seún los principios de inmediación, oralidad, concentración y celeridad".2.Los principios indicados en el número anterior orientarán la interpretación y aplicación de las normas procesales propias de las modalidades procesales reguladas en la presente Ley".

70 Para su general conocimiento reproducimos su literalidad parcial: "1.Los órganos judiciales rechazarán de oficio en resolución fundada las peticiones, incidentes, y excepción formuladas con finalidad dilatoria o que entrañen abuso de derecho. Asi mismo corregirán los actos que al amparo del texto de una norma, persigan un resultado contrario al previsto en la Constitución y en las leyes para el equilibrio procesal, la tutela judicial y la efectividad de las resoluciones. 2.Quienes no sean parte en el proceso deben cumplir las obligaciones que les impongan los Jueces y Tribunales ordenadas a garantizar los derechos que pudieran corresponder a las partes y asegurar la efectividad de las resoluciones.3(...)". 
correlatividad en el planteamiento que es una clara manifestación de la importancia que aquéllos le merecen al legislador: con tal cita encadenada de los "deberes" se enfatiza la relevancia de los "principios"; y por eso es que en la secuencia expositiva, lógicamente, primero se citan los "principios" y después los "deberes".

De los variadísimos comentarios que nos sugieren ambos pasajes procesales sólo unos pocos deben ser atendidos en esta nuestra Ponencia si no es que queremos extralimitarnos, pero nos alivia el compromiso pensar que todos nos conducen a una doble pero encadenada pregunta: ¿son "la inmediación, oralidad, concentración y celeridad" (ex. art. 74.1 cit.) auténticos principios del proceso tal y como se desprende la literalidad de los citados artículos, o, realmente lo son del procedimiento?; ¿Son cuatro, o en realidad sólo lo es uno y el resto consecuencias del mismo?

A continuación dedicaremos nuestra atención a tratar de tales interrogantes, pero antes queremos dejar apuntadas dos consideraciones previas que pueden ayudarnos a plantear tales reflexiones. La primera para recordar que según nuestra normativa procesal el órgano jurisdiccional social competente resuelve el conflicto en instancia única, dato de interés para después tratar de todos los criterios del procedimiento, pero en especial, de la oralidad y concentración procesal. La segunda para reiterar que no siempre resulta pacífico distinguir con nitidez los principios del proceso de los principios o criterios del procedimiento; dificultad de la que da cuenta la simple pero didáctica cita doctrinal siguiente:

Resulta así que cuando el art. 74 de la LPL se refiere a los "principios
del proceso" está aludiendo en realidad a los principios del procedi-
miento y, además, presenta como principios distintos los de inmedia-
ción, oralidad y concentración, cuando se trata de manifestaciones de
un único principio, el de oralidad, del que los demás son consecuencia
ineludibles",

de la que se desprende que existen discrepancia en punto a distinguir entre principios del proceso y criterios del procedimiento, y opinión de la que además se observa que no se incluye referencia expresa alguna sobre el criterio de "celeridad", criterio el cual, en cambio, sí consta en la enumeración elaborada por el repetido ordinal 74 de la ley de ritual, omisión que como comprobaremos líneas abajo no es un olvido sino una valoración de fondo sobre la entidad y significado del mismo.

Apuntadas las cuestiones previas relatadas, recuperemos el hilo expositivo anunciado y así pasemos a dar respuesta a las preguntas que nos hemos planteado en

71 MONTERO AROCA, J. Particularidades de la prueba en el proceso laboral. Procedimiento, objeto y medios. Especial referencia a la prueba documenta, En: AGUSTÍ JULIÀ, J. La prueba en el proceso laboral. Madrid: Cuadernos de Derecho Judicial, nún. XXIII/1997. Escuela Judicial. Consejo General del Poder Judicial, 1998, pág. 191. 
torno a los ordinales 74 y 75 del TRLPL, valoraciones que articularemos en los puntos siguientes.

$\left.1^{a}\right)$ El legislador tilda, en repetidas ocasiones, de "principios del proceso" a los cuatro siguientes: inmediación, oralidad, concentración y celeridad, citados sean en el preciso orden en el lo hace (art. 74.1 TRLPL); cuestión distinta es que, como concretaremos, somos de la opinión que los mismos no son auténticos principios del proceso laboral. Añade el mismo ordinal que tales principios lo son tanto del "proceso laboral ordinario" como de "las modalidades procesales" (art. 74.2 TRLPL), terminología que rezuma el interés que tiene el legislador de poner de manifiesto que tales criterios se proyecten a toda actividad propia de la potestad jurisdiccional; es por eso que nosotros desde buen principio nos hemos referido, y así lo haremos - salvo cuando indiquemos lo contrario -, al proceso laboral (ordinario) en tal sentido omnicomprensivo.

$2^{a}$ ) Tales denominados "principios" obligan - imperativamente: "interpretarán”, “aplicarán”, “orientarán”- a los Jueces y Tribunales tanto con ocasión de interpretar como de aplicar "las normas reguladoras del proceso" (art. 74.2 TRLPL), de la misma manera que debemos entender que obligan a todos y cuantos intervienen en el procedimiento, sean a o no parte (arts. 74 y 75 citados). Al respecto de la literalidad de los mandatos contemplados en el repetido artículo 74 hemos de formular un par de puntualizaciones. El legislador se refiere a "principios del proceso", pero a nuestro parecer, son criterios - no principios - del procedimiento - no del proceso - o pautas práctico-operativas para implementar las normas procesales que regulan el procedimiento de acuerdo con la función del proceso laboral: si todas las reglas generales importantes alcanzaran la condición de principio, nada sería, realmente, un principio jurídico; los principios generales, salvo excepciones colaterales, no constan citados como tales en las normas, sino que se construyen deduciéndolos de varias manifestaciones homogéneas de los mismos de las que sí da cuenta la norma escrita. En este sentido, doctrina autorizada, al tratar de la concentración, oralidad, celeridad e inmediación tratar en el repetido ordinal 74 de nuestra ley de ritual se refiere, a "caracteres generales del proceso del trabajo" 72.

$\overline{72}$ Alonso Olea, M. y Alonso garcíA, B. Derecho Procesal del Trabajo. Madrid: Thomson-Civitas. 2008, pág. 138. 
Así mismo se previene que son "principios" interpretativos a la vez que aplicativos, no obstante, tenemos para nosotros que son más de lo segundo que de lo primero: el auténtico canon hermenéutico las normas procesales laborales es el tutelar (pro operario adjetivo) cuyas manifestaciones más sobresalientes son la rapidez y la igualdad de las partes procesales, dicho sea todo ello en los términos expuestos; mientras que los criterios del procedimiento laboral - inmediación, oralidad, concentración y celeridad - son la concreción o puesta en práctica o en escena de los principios de igualdad real de las partes del proceso de la rapidez del mismo.

$\left.3^{a}\right)$ El artículo 75.1 citado, es una muestra del encomiable esfuerzo realizado por el legislador para explicitar, conceptual y sistemáticamente, el por qué y el para qué de los criterios generales del procedimiento a la vez que para presentarlos como una explicitación más de lo que es y significa el proceso laboral.

El precepto establecido por tal pasaje del TRLPL ya ha sido objeto de un primer comentario al que ahora nos remitimos, y al que aquí añadimos que la terminología del mismo -"rechazarán"... "corregirán"- pone de manifiesto el tipo de conducta activa ("(...) de oficio (...)") que el legislador reclama de los órganos del orden social de la jurisdicción y del protagonismo que les confiere para lograr que el procedimiento responda (inmediación del juzgador, diremos después), fielmente, a los principios de igualdad real de las partes ("equilibrio procesal") y de rapidez procesal que exige el derecho subjetivo a una tutela judicial efectiva ("tutela judicial y la efectividad de las resoluciones") reconocido en la norma de normas ("la Constitución"). Ya lo hemos pergeñado, pero no está de más insistir: este tipo de implicación procesal que el legislador ordinario impone a los órganos de referencia se aviene muy bien con el tipo de intervensionismo de los poderes públicos dispuesto en el ordinal 9.2 de la $\mathrm{CE}$, apreciación que nos permite concluir estos puntos de la forma en la lo hacemos en el siguiente.

$4^{2}$ ) El Derecho Procesal del Trabajo se concibe como tuitivo y el principio que lo inspira es el tutelar procesal (versión adjetiva del principio pro operario sustantivo); la principal institución del tal Derecho, el proceso, se inspira, especialmente, en los principios de igualdad real de los sujetos procesales y en el de la rapidez procesal; y, el procedimiento laboral, se ordena a la luz y amparo de los criterios de inmediación, oralidad, concentración y celeridad, para que, en definitiva y por todo ello, resulte factible el ejercicio real del derecho subjetivo a una tutela judicial efectiva por parte de los trabajadores. En este punto hemos de recordar - parafraseando a Thering - que el Derecho comporta seguridad jurídica, pero que también debe conllevar seguridad de goce de los derechos. 
19. Siguen nuestras reflexiones sobre cada uno de tales criterios generales que disciplinan y dan contenido a los diferentes y sucesivos actos que componen el procedimiento laboral.

Cierto es que el repetido artículo 74.1 enumera cuatro criterios y que a cada uno de los mismos le podríamos reconocer personalidad propia y hacerlos objeto de sendos comentarios, pero por coherencia conceptual y unidad expositiva, somos de la opinión que es mejor correr el riesgo de plantear desde el principio que uno de ello es el predominante -el criterio de oralidad- y que sobre el mismo basculan los tres restantes ${ }^{73}$. La opción de magnificar el criterio de oralidad del procedimiento es bastante común en la doctrina -“...bay uno que se sobrepone en importancia a los demás; se trata del principio de oralidad..." ${ }^{\text {ग74 }}$, y acertada según nuestro parecer, no sólo porque el significado práctico de los tres restantes criterios se advierte mejor si se los considera cuasi-consecuencia del mismo, sino también, o principalmente, porque la oralidad procesal es el criterio que mejor razón da de la igualdad procesal y de rapidez y efectividad de la tutela judicial que define el proceso laboral; planteamiento discursivo, que por lo demás, bien podemos avalar con aquel desideratum constitucional que reclama que "el procedimiento será predominantemente oral (...)" (art. 120.1 de la $\mathrm{CE}$ ). Cita constitucional de la que a su vez podemos deducir dos tesis útiles para mejor sustentar nuestro discurso: su literalidad da nuevo respaldo a quienes tildamos a la oralidad como criterio del procedimiento y no como principio del proceso, sin que con ello queramos restar importancia alguna al mismo; y su lógica finalista, da apoyo a quienes opinamos que un proceso como el laboral, que se caracteriza por la asimetría de su litis, sea uno de los más necesitados de lo que el constituyente propone y persigue con tal mandato.

La referida oralidad procesal es pues un criterio rico en matices por la significación que tiene, tal es así que incluso, como hemos comprobado, muchas veces se le califica de principio, riqueza de contenido que hemos de resumirla como sigue, no sin antes recordar que, incluso, no resulta extravagante ni desconocido tratar de la ideología de la tutela judicial efectiva tomando como punto de referencia la oralidad de los procesos: ${ }^{75}$

$1^{\text {a) }}$ La oralidad es un criterio preferente: no se impone en todos los actos procesales (demanda y acta de juicio son actos escritos, ex arts. $80.1 \mathrm{y}$

73 BODAS MARTÍN, R.: El juicio oral. En: "FOLGUERA CRESPO, J. (Director): E1 proceso laboral en la jurisprudencia del Tribunal Constitucional. Madrid: Consejo General del Poder Judicial. Cuadernos de Derecho Judicial, 1996.

74 LUELMO MILLÁN, M. y RABANAL CARBAJO, P. Los principios inspiradores del proceso laboral... op. cit., pág. 68.

75 Vid, Derecho Procesal Civil. Universidad de Lima. Perú: XXI Jornadas Iberoamericanas, 2008. 
89 del TRLPL, respectivamente), pero en otros impera con exclusividad (vista oral del juicio) por mandato legal. El legislador y el juzgador bien saben que verba volant, scripta manent, y por ello calculan y ajustan las dosis de oralidad - predominante- y escritura -secundaria- a combinar para el buen fin del proceso: la rapidez que imprime la oralidad no tiene porque quebrar la seguridad, y mucho menos si el juzgador tiene las competencias y aptitudes oportunas.

$2^{a}$ ) Pero ocurre que, la oralidad así entendida, exige inexcusablemente, que el juez o tribunal tenga atribuidas ciertas prerrogativas peculiares que le permitan participar activamente y dirigir con imparcialidad el procedimiento de tal manera - con autoridad, proximidad e inmediatez que permita comprobar que el juez "preside" el acto - que la seguridad y efectividad del proceso queden debidamente garantizadas: la imparcialidad del juez así entendida explica que esté situado entre las partes, pero por encima de las mismas. Y a su vez, si el referido criterio de oralidad requiere de juzgadores activos y rápidos, no resultará sobrante reconocer que también deberán estar tan debidamente formados como bien asistidos de los medios necesarios: la oralidad, siempre conlleva exigencias para con todos si quiere ser efectiva en punto a lo que persigue; el propio juez que preside un acto oral no puede hacer dejación alguna de su inmediación, pues vería como su función se dificultaría en la práctica ala vez que generaría efectos negativos indeseados. La conocida polémica y eternas dudas sobre si el juez social aceptará de buen grado o no la instructa del demandado a modo de contestación escrita a la demanda es un dato muy revelador del profundo calado - y de las consecuencias prácticas - que tiene el criterio de oralidad a la vez que de la pervivencia de ciertas reservas que siguen existiendo sobre la bondad del mismo. ${ }^{76}$

Todas estas precisiones jurídicas, y otras más que podríamos formular, son las que conceden al juez social un perfil propio tal que permite descubrir cual es el verdadero sentido jurídico de quienes defienden que dicho juzgador "debe estar dotado de un sensibilidad especial" investigadores iberoamericanos que al tratar de la "Autonomía procesal del Derecho del

76 GARCÍA BECEDAS, G.: Los principios informadores del proceso laboral (Algunas reflexiones críticas en torno a la oralidad, celeridad y concentración), En: AA.VV. E1 proceso laboral. Estudios en homenaje al Profesor Luis Enrique de la Villa Gil. Valladolid:. Lex Nova, 2001, págs. 203 a 210.

77 HERRERA CARBUCCIA, MR.: Importancia de la Unidad de Jurisprudencia Labaral. Análisis y Discusión. Gaceta Laboral, Vol. 12, núm. 1 de enero de 2006. 
Trabajo" con criterio realista digno de encomio apuntan que "Es el espíritu nuevo, peculiar, distinto del que imperan las restantes ramas del derecho de mucho mayor sensibilidad y proximidad con la vida real el que obliga indispensablemente a jueces diferentes especiales" ${ }^{78}$

$3^{\text {a) }}$ En la nota anterior, hemos querido comprobar y explicar el por qué la oralidad nos lleva hasta la inmediación procesal (y hasta la concentración y la celeridad): teníamos pues razón al decir que aquél criterio es el origen o causa de los tres restantes, inmediación del juzgador incluida.

$\left.4^{2}\right)$ Omitimos, por conocidas, citas pormenorizadas de actos del procedimiento en los que la oralidad resulta ser ejemplificativa del sentido que le hemos otorgado, aunque como compendio de tales, recordamos: que el demandante "ratificará o ampliarâ" la demanda al inicio de la vista oral del juicio; que el demandado "contesta" los hechos de la demanda en el mismo acto (art. 85 TRLPL); que ambas partes formulan sus conclusiones verbalmente (art. 87 TRLPL); y que, incluso, está prevista la posibilidad de que el órgano juzgador dicte autos verbalmente y sentencias in voce (art. 50 LPL). A todo eso responde, a la vez que le da mayor consideración, el que las partes harán uso de la "palabra" cuantas veces el Juez o Tribunal lo estime necesario (art. 85.3 TRLPL).

$5^{\text {a) }}$ Desde el principio de nuestro relato hemos mantenido y argumentado que el carácter tutelar del Derecho Procesal, y consecuentemente, que los principios inspiradores del proceso - igualdad real de las partes y rapidez para la efectividad de las resoluciones - lucen especialmente en la fase probatoria - precisamente porque es la esencial en punto a la fijación de hechos y subsiguientes pretensiones-, pues bien, siguiendo el mismo orden del discurso, ahora, hemos de apuntar que en tal fase del procedimiento es en la que el criterio de la oralidad del procedimiento tiene atribuido su papel estelar, significación que nos obliga a dejar para un aparato propio la pormenorización de la cuestión.

$\left.6^{a}\right)$ Y para concluir nuestras consideraciones sobre el vasto alcance del criterio de la oralidad hemos de señalar que, en nuestra opinión, el mismo facilita la accesibilidad a las partes al proceso a la vez que ayuda a hacer fácil y sencillo lo que no siempre lo es (la sencillez del derecho versus sencillez procesal), a garantizar la publicidad del proceso, a favorecer la gratuidad y la economía procesal, y a evitar formalismos innecesarios; en definitiva y en último término, la oralidad viene a favorecer,

78 Informe de Investigación CIJUL (Centro de Información Jurídica en Línea -Convenio Colegio de Abogados y Universidad de Costa Rica-), sobre "Principios rectores del proceso laboral" http:// cijulenlinea.ucr.cr/condition.htm. 
no sólo la rapidez procesal, que bien podría parecer su única meta, sino también, y no con menos intensidad, la igualdad de las partes procesales pues a favor de la misma bascula la sencillez, la publicidad y la gratuidad refereidas.

18. Siguen a continuación unos escuetos apuntes sobre los restantes tres criterios del procedimiento laboral, sin que olvidemos que, en buena parte, tales opiniones son deudoras de las que nos ha merecido el criterio de oralidad, dicho sea, sin desconocer que cada uno de los referidos criterios del procedimiento aporta referentes para completar la configuración del mismo.

19. La concentración - realizar el mayor número de actos en el menor tiempo posible - explica que, siendo cierto que el procedimiento es una sucesión (pre)ordenada de actos procesales agrupados en fases, también lo es que la unidad estructural y continuidad en el tiempo entre las mismas es tal que más bien parece que el procedimiento se desarrolla en un solo acto, quizás por ello es común referirse a la unidad de acto, acto de juicio o a única audiencia, y en ocasiones así hacerlo confundiendo la parte con el todo: $v$. gr., la citación de la partes es única para el acto de conciliación judicial y para inicio del acto de juicio oral, y que la suspensión del procedimiento es una posibilidad procesal excepcionalísima. Pero la unidad de actuación - ni la rapidez - no desdice la necesidad de que las actuaciones procesales deban respetar el orden preestablecido (momento procesal oportuno: preclusión de actos de acuerdo tanto con términos como con plazos establecidos) si se quiere evitar que se pueda anular todo lo actuado; preclusión que, por lo de orden que conlleva, favorece la propia concentración $y$, en definitiva, la rapidez pretendida.

20. La inmediación del juez no sólo supone su presencia y contacto personal y directo con el material actuado y todos los intervinientes -circunstancia ya de por si relevante a nuestros efectos: ve y oye in situ y en directo a todos los intervinientes-, sino que además, dirige, impulsa y controla personalmente el desarrollo del proceso con tanta imparcialidad como autoritas: estamos pues hablando de una inmedición de forma y de fondo. Esta inmediación explica que el protagonismo del juzgador es presidencialista - el juez "preside" el acto (art. 98 TRLPL)-, y se entiende mejor si se tiene presente que el procedimiento también está sometido a la referida concentración y a la rapidez consiguiente, y en definitiva - y este dato es muy importante en esta exposición-, el verdadero valor de la inmediación es permite que el juez pueda autoconocer personal e íntimamente los hechos reales y se convenza del 
por qué de los mismos, resultando así que le resulta más fácil descubrir la verdad real (primacía de la veracidad como una manifestación más del realismo que relega el valor de la verdad aparente).

Señalamos a continuación una aportación más práctica en punto a la relevancia de este criterio: si reseguimos nuestro TRLPL no encontraremos una verdadera y auténtica excepción significativa de la aplicación de la inmediación, pero en cambio no resulta nada difícil localizar supuestos en los que su puesta en escena práctica es muy reveladora, así ocurre, por ejemplo, cuando se previene que en el caso de que el juez que ha presidido el acto no puede dictar sentencia, deberá celebrarse nuevamente (ex. art. 98 TRLPL), o cuando se sienta que "Las partes harán uso de la palabra cuantas veces el Juez o Tribunal lo estime necesario" (art. 85.3 TRLPL). Este último supuesto también lo hemos traído a colación para ejemplificar la oralidad procesal, coincidencia que pone de manifiesto la inevitable interrelación entre oralidad e inmediación, a la vez que evidencia una vez más una clara previsión legal, cual es que la autoritas que conlleva la inmediación no es ilimitada, pues el juzgador no la puede ejercer cuando y como lo tenga a bien, sino únicamente cuando lo considere "necesario". La inmediación procesal y el estrellato del juez, en si mismo considerados en nada desmerece la imparcialidad del juzgador social.

21. Nos queda por exponer nuestras observaciones sobre la celeridad como cuarto criterio del procedimiento: ¿verdad que el proceso pretende restituir el bien jurídico tutelado?, pues bien, por pura lógica, el buen fin y la efectividad de tal operación exige una rapidez de tal intensidad que no resulta extraño que el legislador presione el acelerador cuando el proceso se tramita o desarrolla, es decir durante el procedimiento.

Frente a quienes toman la expresión "celeridad" (ex 74.1 del TRLPL) como la base para fundar el principio de rapidez del proceso, nosotros somos de la opinión que dicha exigencia, es, simplemente, un criterio del procedimiento y como tal una más de las manifestaciones de dicho principio (si el proceso ha de ser rápido, cada acto y fase, se han de suceder e hilvanar en el tiempo con celeridad: ajuste de términos y acorte de plazos). Es más, tenemos para nosotros que la celeridad, así constreñida a sus justos términos, no es precisamente uno de los criterios del procedimiento más significativo desde una visión cualitativa de los mismos: dudamos sinceramente sobre si en esencia ¿es más rápido un proceso por la celeridad del procedimiento que por la oralidad y concentración del mismo?; es más, dudamos si formularnos tal pregunta tiene sentido debido a lo inconveniente que resulta compartimentar los criterios de referencia. La celeridad, más que una idea, es una técnica operativa entre cuyas manifestaciones prácticas previstas en ley de ritual podemos citar, a modo de v. gr., las siguientes: la consistente en fijar términos concretos para el desarrollo de 
las actividades procesales, y, a su vez, la de señalar plazos cortos para las actuaciones procesales; técnicas que imprimirán mayor celeridad si el derecho en litigio es, por ejemplo, constitucional de rango fundamental.

La celeridad como tal complementa los restantes criterios del procedimiento - el de oralidad, de concentración y el de inmediación -, y todos ellos combinados dan cuerpo al principio de rapidez del proceso; pero en nuestra opinión, del estudio de la normativa procesal vigente, se desprende que nuestro proceso es más rápido, por mor de su oralidad (en un marco de concentración e inmediación judicial) que por las auténticas pautas de celeridad preceptuadas como tales, sin que por ello queramos restar significación alguna a la celeridad de referencia ni, tampoco, dejar en el olvido que, en ocasiones, establecer plazos que por breves resultan de difícil cumplimiento provoca efectos negativos. ${ }^{79}$ Líneas arriba hemos apreciado como una voz autorizada sostiene que la inmediación, la concentración y la oralidad son más pautas del procedimiento que principios del proceso, y, a mayor precisión, que la inmediación y la concentración son consecuencias lógicas de la oralidad; ${ }^{80}$ razonamiento que por el sólo hecho de omitir toda referencia a la celeridad procesal, minusvalora el significado de la misma, apreciación que se confirma si comprobamos como, posteriormete, nuestro autor califica a la celeridad como una simple "consecuencia" (que no de "principio") de la inmediación y concentración: ${ }^{81}$ en este sentido, nosotros, hemos sostenido que la significación de la celeridad, en si mismo considerada, cotiza a la baja cuando se trata de valorar conjuntamente el significado de los criterios del procedimiento como tales.

Para ejemplarizar la celeridad podría citar no pocos supuestos puntuales, a modo de ejemplo sirva el siguiente. Varios ordenamientos procesales nacionales ${ }^{82}$ al tratar

79 Recuérdese aquí que la propia Exposición de Motivos de la precitada Ley 1/2000, de 7 de enero, de Enjuiciamiento Civil apunta que los plazos breves, no son en si mismo considerados, "una panacea" de la rapidez ni de la efectividad de la sentencia.

80 Rememoremos la cita de autor en cuestión: "Resulta así que cuando el art. 74 de la LPL se refiere a los $<<$ principios del proceso $>>$ está aludiendo en realidad a los principios del procedimiento y, además, presenta como principios distintos los de inmediación, oralidad y concentración, cuando se trata de manifestaciones de un único principio, el de oralidad, del que los demás son consecuencia ineludibles" (MONTERO AROCA, J. Particularidades de la prueba en el proceso laboral. Procedimiento, objeto y medios. Especial referencia a la prueba documenta. En: AGUSTÍ JULIÀ, J. La prueba en el proceso laboral. Madrid: Cuadernos de Derecho Judicial, núm. XXIII, 1997. Escuela Judicial. Consejo General del Poder Judicial, 1998, pág. 191).

81 MONTERO AROCA, J. Particularidades de la prueba en el proceso laboral. Procedimiento, objeto y medios. Especial referencia a la prueba documenta. En: AGUSTÍ JULIÀ, J. La prueba en el proceso laboral. Madrid: Cuadernos de Derecho Judicial, núm. XXIII/1997. Escuela Judicial. Consejo General del Poder Judicial, 1998, nota a pié de página núm. 11, pág. 191.

82 En el ámbito iberoamericano, y por todos, vid.: MURGAS TORRAZZA, R. La tutela judicial contra los despidos nulos por discriminación. Experiencia comparada. Revista Derecho del Trabajo, núm. 3 (extraordinaria) 2007 (Venezuela), págs. 379 a 395 (En este número de 
de la modalidad procesal de tutela de los derechos fundamentales establecen algo similar a lo previsto en nuestro artículo 177 del TRLPL:"La tramitación de estos procesos tendrá el carácter de urgente a todos lo efectos, siendo preferente de todos los que se sigan en el Juggado o Tribunal'. Pues bien, en este precepto se observan varias cuestiones dignas de mención. En primer lugar se distingue entre el proceso y su "tramitación" (es decir el procedimiento), aportación que interesa por lo comentado en apartados supra. En segundo término, se observa que lo que en realidad se pretende es lograr todavía mayor rapidez, y para ello se establecen dos criterios operativos que actuando a la par aceleran la sucesión de actos procesales en el tiempo, la "urgencia" "a todos los efectos" (acortando todavía más algunos plazos y, consecuentemente, potenciando más la concentración) y la "preferencia" frente a otros litigios todavía; plus de rapidez que se explica, precisamente, porque la naturaleza y rango del derecho a restituir exige la máxima rapidez. Ayuda a explicar el sentido de la rapidez procesal que pretende el citado ordinal 177 del TRLPL el comprobar que tal operación tiene entronque con la Constitución: partiendo del reconocimiento del derecho a una tutela judicial efectiva previsto en el repetido pasaje 24 de la CE, el artículo 53 del mismo texto legal, al tratar de la garantía de los derechos constitucionales fundamentales ya establece que el titular de los mismos podrá reivindicarlos ante los tribunales ordinarios "por un procedimiento basado en los principios de preferencia y sumariedad"; previsión constitucional que además nos resulta útil por partida doble: para advertir que en sede constitucional también se distingue entre proceso y procedimiento, y para, comprobar que, no obstante, a nadie -ni tampoco al constituyente- le resulta fácil diferenciar entre principios del proceso y criterios del procedimiento. Y digamos por último que no es por casualidad que el principio de rapidez se intensifique en el mismo supuesto en el que ocurre igual con el principio de igualdad de las partes procesales, coincidencia que comprobaremos en el apartado que sigue, y que por lo demás, debemos valorar desde una doble perspectiva: porque da buena cuenta de la estrecha interdependencia que existe entre los dos principios inspiradores del proceso entre si, y entre éstos y todas las manifestaciones de los mismos; y porque tal coincidencia no se da en cualquier fase del procedimiento, sino en una muy elocuente a nuestros efectos, en la fase probatoria, de la que ya hemos apuntado merece mayor dosis de tutela en sede judicial.

la Revista cit., monográfico sobre el Derecho del Trabajo en los albores del siglo XXI", se recogen las "Memorias y comunicaciones del $<<$ Congreso Internacional de Derecho del Trabajo >> Isla Margarita-Venezuela, abril-mayo de 2007”); GUZMÁN, HB (ed. a cargo de). Derecho Procesal del Trabajo. Moca (Republica Dominicana): Editora Dalis, 2002, págs. 69 a 104; y, HERRERA CARBUCCIA, MR. (Coord.): Estudios de procedimiento laboral en Iberoamerica. Homenaje a Don Rafael Alburquerque. (Tomo I y Tomo II ), Republica Dominicana: Asociación Iberoamericana de Derecho del Trabajo y Librería Jurídica Internacional, 2007. 


\section{El especial reflejo de los Principios del Proceso y de los Criterios del Procedimiento en la fase probatoria}

22. La prueba -"el medio más eficaz.para hacer que el juzgador conozca la verdad (...) en el proceso" 83 - tiene por finalidad ofrecer al juez "elementos de convicción" sobre la veracidad, principalmente, de los hechos expuestos y sobre los que los mismos basan los respectivos derechos objeto de pretensión en el litigio (art. 97.1 TRLPL; principio dispositivo: da mibi factum, dabo tibi ius), ${ }^{84}$ hechos expuestos y derechos alegados sobre los que el jugador deberá sustentar y fundar su resolución judicial. Parece pues lógico que esta crucial operación - fijar la verdad a partir de la convicción y certeza del juez por medio de pruebas - sea la más necesitada de la igualdad y rapidez procesal, y de la oralidad, inmediación, concentración y celeridad procedimental. ${ }^{85}$ Sobre la alta - y clásica ${ }^{86}$ - significación de la fase probatoria del iter jurisdiccional y del laboral en particular permítasenos el siguiente recurso dialéctico: somos de la opinión que hablar del Derecho o probatorio es un exceso jurídico, como también lo es, sin duda alguna, hacerlo del Derecho probatorio laboral, pero quizás, en este caso, lo sea algo menos. ${ }^{87}$

En este quinto y último apartado de la Ponencia comentaremos ciertos preceptos del LPL que ponen de relieve lo anteriormente afirmado, ${ }^{88}$ partiendo siempre de la base que "el principio de igualdad, que ha de estar siempre presente en la fase probatoria como una de las garantías esenciales protegidas por el art. 24 CE", evitando así "situaciones de supremacía... privilegio de alguna de las partes(...)". ${ }^{89}$

33 VALladARES CASTILLO, F. Derecho Procesal del Trabajo. Managua: Bitecsa, 2000, p. 47.

84 BENTHAM, J. Tratado de las pruebas judiciales. (traducción: Manuel Osorio) Granada: Comares, 2001; y, GONZÁLEZ DÍAS, FA. Los medios de prueba en el proceso laboral. Madrid: Thomson-Civitas, 2005.

85 GARCÍA-PERROTE ESCARTÍN, I. Prueba y proceso laboral. Derecho Privado y Constitución. núm. 4/1994, págs. 163 a 221; idem: La prueba en el proceso de trabajo. Madrid: Civitas, 1994.

86 Por todos, vid. CABRERA BAZÁN, J. La prueba en el proceso de trabajo. Revista de Política Social, núm. 82;1969.

87 GIL PLANA, J. La prueba en el proceso laboral. Disposiciones generales. ThomsonAranzadi. Cizur Menor, 2005, pág. 32, afirma: “(...) si en alguna institución procesal se ha asumido de forma notable los principios procedimentales típicos del procedimiento laboral es en la prueba".

88 Obviamos detallar que los denominados "actos preparatorios y medidas precautorias" (arts. 76 a 79 TRLPL), incluida entre éstas "la práctica anticipada de las pruebas" (art. 78 TRLPL), deben ser considerarse como manifestaciones del derecho a una tutela judicial efectiva (art. 24 CE); al respecto, vid. SALINAS MOLINA, F. Medidas cautelares y prueba anticipada, en: “: “AGUSTÍ JULIÀ, J. La prueba en el proceso laboral. Madrid: Cuadernos de Derecho Judicial (1997). Escuela Judicial. Consejo General del Poder Judicial, 1998, págs. 113 a 176; y, BLASCO PELLICER, A. Las medidas cautelares en el proceso laboral. Madrid: Civitas, 1996.

89 Sentencia Tribunal Constitucional 227/199, de 28 de noviembre, en su 5 y último FJ, y en concreto en párrafo penúltimo del mismo. 
23. No resulta nada original - al contrario - apuntar que la inversión de la carga de la prueba - o "del porte del fardo", según gráfica expresión dominican $a^{90}$ - que en ocasiones establece la normativa procesal laboral en favor de los intereses del trabajador es uno de los hechos paradigmáticos que mejor explican la conclusión que queremos extraer y probar en este quinto apartado de nuestra exposición y de la que ya da cuenta la rúbrica del mismo y cuanto hemos adelantado al respecto; pero si que resulta de sumo interés preguntarse sobre el por qué, cómo, y para cuándo el artículo 179.2 $2^{91}$ del TRLP establece dicha inversión desvirtuando así de plano la regla tan lógica como clásica que exige que quien alega debe probar. La respuesta a tales cuestiones no puede ni debe ser aprovechada para exponer con detalle la teoría general de tal inversión - ni tan siquiera para plantearse si se trata o no de una auténtica inversión de la prueba -, debe ser breve y únicamente dirigida a extraer reflexiones útiles para las cuestiones objeto de nuestra reflexión en esta Ponencia. $^{92}$

Una interpretación lógica del artículo 179.2 citado permite afirmar que en el mismo se viene a reconocer que entre el trabajador-actor y el empresario-demandado existe una desigualdad originaria, y es por ello -y no por otra razón- que en el mismo se establece la denominada inversión de la carga de la prueba para que así el juzgador pueda restablecer la igualdad procesal real de las partes a favor del derecho a una tutela judicial efectiva (de la igualdad a la efectividad): ya lo hemos escrito, el titular del poder de organización y dirección de la empresa tiene, en ciertos casos, mayor posibilidad material de disponer y utilizar (u ocultar para impedir que otros la utilicen en su contra) una prueba que la que tiene quien le presta trabajo en régimen

90 Transcrito de ALONSO OLEA, M. y ALONSO GARCÍA, B. Derecho Procesal del Trabajo. Madrid: Thomson-Civitas., 2008, pág, 209, nota a pie de página 41, que atribuye la expresión a HERNÁNDEZ RUEDA, L. Derecho Procesal del Trabajo. $3^{a}$ ed. Santo Domingo, 1997, págs. 164, 167 y 170. A lo que nosotros añadimos que, tal expresión, también la utiliza el citado autor en su estudio: Del régimen de la prueba. En: GUZMÁN, HB. (ed. a cargo de): Derecho Procesal del Trabajo.Moca (Republica Dominicana): Editora Dalis. 2002, pág. 273 (este ensayo es, en parte el comentario del autor al art.541 del Código de Trabajo -de la República Dominicana- en su obra: Código de Trabajo anotado. Vol. II. Arts. 317 al 738. Santo Domingo: Instituto de Estudios del Trabajo, 2002, págs. 331 a 339).

91 Por razones obvias, conviene reproducir el literal procesal que nos sirve de ejemplo: "En aquellos procesos en los que las alegaciones de la parte actora se deduzca la existencia de indicios fundados de discriminación por razón de sexo, origen racial étnico, religión o convicciones, discapacidad, edad u orientación sexual, corresponderá al demandado la aportación de una justificación objetiva y razonable, suficientemente probada, de las medidas adoptadas y de su proporcionalidad" (art. 179.2 TRLPL). El art. 81 del mismo texto de ritual extiende la tutela a "los demás derechos fundamentales y libertades públicas(...)".

92 MONEREO PÉREZ, JL. La carga de la prueba en los despidos lesivos de los derechos fundamentales. Valencia: Tirant lo Blanch, 1996. 
de ajenidad y subordinación cuando actúa como actor; y por ello cuando el juez ha apreciado libremente las alegaciones del actor-trabajador y no ha podido lograr el pleno convencimiento de la veracidad de las mismas, carga al demandado-empresario con la obligación de convencerle de que su actuación ha sido regular. Es, en definitiva, un mandato del legislador procesal fruto del principio tutelar (a modo y semejanza del principio pro-operario en los términos relatados) que posibilita reequilibrar situaciones personales desiguales, a la vez que es una operación diseñada para buscar la verdad real más que la formal.

De esta manera hemos resumido nuestra opinión sobre el por qué y el para qué de lo prevenido en el artículo 179 de la ley de ritual. Y un detalle más por lo que a continuación diremos: adviértase desde ahora mismo que el legislador, cuando se refiere a los citados "indicios" no los califica de suficientes, mientras que, cuando hace lo propio con la prueba del empresario, sí que la califica, expresamente de "suficiente".

Y si nos preguntamos cómo construye la inversión el legislador podemos decir que lo hace de la siguiente manera: no obliga al trabajador-actor a probar nada, sino simplemente a aportar simples "indicios" que conformen la convicción del juzgador en un sentido determinado, mientras que, contrariamente, sí que impone al empresario "probar suficientemente" que su actuación es regular; es pues un paradigmático trato doblemente desigual entre desiguales a favor de la igualdad real procesal: descarga de la prueba al actor-trabajador sin necesidad de probar nada, obligando al empresario a que pruebe suficientemente que su conducta es ajustada derecho.

Tal inversión del onus probandi se establece $-v$. gr.- al tratar el TRLPL de una modalidad del proceso laboral caracterizada por la naturaleza del derecho en litigio, un derecho constitucional de rango fundamental $-v \cdot g r$. - una discriminación del trabajador por razón de género o raza-, pero la inversión no es explica sólo por ello, sino también, y de forma especial, entendemos nosotros, porque la supuesta infracción del empresario puede resultar difícil de (com)probar por lo fácil que le podría resultar ocultarla al abrigo de su poder de dirección empresarial, resultando así que se podría originar una desigualdad en una fase de tanta relevancia como la probatoria. Tenemos pues a la vista un modélico ejemplo de cómo el legislador regula a favor de la igualdad real de las partes, voluntad y mandato legal que, a su vez, deberá ser tenido en cuenta por quien juzga con ocasión de interpretar y aplicar toda la normativa procesal. Pero además, recordemos que esta modalidad procesal en la que se practica la referida inversión de la carga de la prueba se tramita al amparo de la "urgencia" y "preferencia" a las que hemos aludido al citar el artículo 177.1 del TRLPL, resultando así que en el mismo supuesto contemplamos con claridad la proyección de los dos principios inspiradores del proceso (igualdad y rapidez), de la misma manera que podríamos detallar como en este caso los criterios del procedimiento 
- oralidad, inmediación, concentración y celeridad - tienen su particular manera de materializarse, es por ello que, por razones de fondo, se advierte la vitalidad del carácter tutelar del Derecho Procesal Laboral, y por la forma en que se manifiesta ante una "garantía jurisdiccional reforzada"."3

En conclusión, se excepciona pues aquella regla general de juicio que con distinto formulismo establece "Ei incumbit probatio qui dicit, non qui negat" y que "Actori incumbit onus probandi", ${ }^{94}$ y se excepciona, no de cualquier manera sino de la significativa manera que ha sido descrita, lo que nos lleva a pensar que el sentido de tal operación legal bien podría ser tenida como una pauta hermenéutica más para disciplinar cualquier acto de la fase probatoria. Y es por ello que hemos querido encabezar este apartado con el tema de la inversión de carga de la prueba, dejando para el punto que sigue otras manifestaciones del especial reflejo de los principios del proceso y de los criterios del procedimiento en la fase probatoria; hemos pues preferido utilizar el tema de la inversión de la prueba como cabecera más que como cierre y remate de este apartado por entender que así lo merece el tema.

24. A continuación puntearemos aquellas reglas más generales que ordenan los aspectos procesales más particulares que mejor ponen de manifiesto la especial incidencia que los principios del proceso y los criterios del procedimiento tienen en la fase probatoria del mismo; incidencia que adquiere mayor sentido si a la vez se comprueba que la misma se produce en todos los trámites de la actividad probatoria, en punto a la proposición de los medios de prueba, con ocasión de la admisión o no de los mismos por parte del juzgador, y así mismo ocurre cuando la prueba se practica ${ }^{95}$. Comprobemos pues tales reglas procesales y lo que de las mismas se deduce:

$\left.1^{a}\right)$ Las partes pueden proponer (recibimiento a prueba dispositivo y por aportación de parte) y valerse de todos los medios de prueba - incluidos mecánicos de audio y video - para favorecer la verdad real (art. 90 TRLPL), siempre que “puedan practicarse en el acto...” (art. 87.1 TRLPL), y que previamente hayan sido admitidos -in voce - por el órgano judicial (art. 87.2 TRLPL) y con los que los litigantes habrán de concurrir al juicio (art. 82. 2 TRLPL); la prueba de confesión debe ser "verbal" sin admisión de pliegos (art. 91.1 TRLPL); el llamado a confesar que

93 GÁRATE CASTRO, J. La tutela de los derechos fundamentales y libertades públicas por los tribunales laborales. Pontevedra: Edit. Revista Xurídica Galega, 1999, p. 15 y ss.

94 En Código de Justiniano se establecía: "actore non probante, qui convenitur, et sí nibil ipse praestet, obtinebit"; y, "Actore non probatem, reus est absolvendus" (Libro II, Tit. I, ley 4").

95 Sobre estas cuestiones, la doctrina coincide en reconocer las aportaciones realizadas al respecto por el Tribunal Constitucional, y, a modo de $v$. gr. merece cita propia la STC 227/1991. 
no acuda o no responda debidamente se tendrá por confeso (art. 91.1 TRLPL); no se admitan "escritos" de preguntas y repreguntas en la prueba testifical (art. 92.1 TRLPL); en la prueba pericial no se admitan las reglas generales de insaculación (art. 93.1 TRLPL); y el juez valora libremente y en conjunto las pruebas practicadas ante si. Tales reglas generales, claro está, tienen sus excepciones, pero no por ello pierden el valor por el que las hemos citado en este punto de nuestro discurso.

$2^{\circ}$ ) En la misma línea discursiva: el propio órgano judicial " a su criterio puede limitar "discrecionalmente" el número de testigos cuando los considere excesivos o innecesarios (art. 92.1 TRLPL), previsión que toma razón de ser en aquel mandato legal más general que otorga al órgano juzgador un amplio y significativo margen para la admisión y declaración de pertinencia o no de las pruebas propuestas a recibo (art. 87 TRLPL) y que supera el aforismo unus testis nullus testis; resulta pues que como ya hemos razonado el juez esta investido de cierto presidencialismo cuando dirige - activamente (con inmediación procesal, y celeridad procesal versus economía procesal) - el acto tanto desde un punto de vista formal como incidiendo en el contenido de los actos procesales; así mismo, cabe rememorar que el propio juzgador puede hacer a las partes y a los testigos y peritos, las preguntas (orales) que estime adecuadas para el esclarecimiento de los hechos y hacerlo de tal manera que parece correcto decir que se trata de un interrogatorio libre, pero que en ningún caso se debe entender como aportación de prueba por parte del juzgador (art. 87.3 TRLPL) que pudiera contravenir el sentido dispositivo del proceso laboral, posibilidad esta que también rezuma, oralidad, concentración y sin duda alguna y celeridad, y todo ello en favor de poder fijar la verdad real, y porque no decirlo, para garantizar la igualdad real de las partes procesales en beneficio de una tutela judicial real y efectiva.

$3^{a}$ ) A mayor abundamiento enfatizamos lo siguiente. El juez en uso de la inmediación puede - potestativamente, pues - decidir diligencias para mejor proveer en el propio acto del juicio, o incluso, una vez finalizado el mismo pero, claro está, antes de dictar sentencia (art. 95.1 TRLPL), posibilidad que puede caracterizarse como una prueba complementaria pero no una actividad probatoria realizada en sustitución de la de las partes, pues también en este caso debe respetarse lo de dispositivo que tiene el proceso laboral. Y por último y a modo de cierre, debemos resaltar que, concluida la práctica de las pruebas y sin solución de continuidad (idea de concentración y consiguiente celeridad mediante la 
fijación de términos procesales que refuerzan la preclusión) las partes o los defensores formularán "oralmente" (oralidad pues) sus conclusiones de acuerdo con lo reclamado en la demanda y del resultado de la práctica de las pruebas (realce del valor de las mismas en punto a convencer al juez), y una vez así formuladas, si el juez "lo estima oportuno" (inmediación) por considerar que las mismas no le han ilustrado suficiente "sobre las cuestiones de cualquier género objeto de debate" concederá a ambas partes el tiempo que - el juez - "crea conveniente" (celeridad versus seguridad y verdad real) no tanto para que prosigan en su discurso en defensa de sus intereses sin más, sino para que "informen o den explicaciones - al juezsobre los particulares que les designe" (art. 87.5 TRLPL), previsión esta que acentúa más, si cabe, la inmediación procesal al poner de relieve que el poder de dirección del juez no sólo alcanza a cuestiones formales sino también a otras de mucho mayor calado sustantivo. Sabemos que las conclusiones como tales no son, en sentido estricto, un acto de la fase probatoria a la que nos estamos refiriendo, pero huelgan justificaciones detalladas para poder referirnos aquí a las mismas en atención a que las conclusiones se formulan, en el mismo acto (concentración) y, precisamente, "en virtud del resultado de la prueba" (art. 87.4 TRLPL).

No parece pues que nuestro legislador procesal esté dispuesto a que el juzgador dicte una sentencia a partir de ciertas apariencias revestidas de simples formas y formalidades, sino más bien a que lo haga previa deducción de la verdad real, primando así la veracidad propia del realismo frente al simple formalismo. Tenía y tiene pues razón aquella doctrina - citada supra - que razona que por lógica deducción la fase probatoria es la más necesita y beneficiada del don tutelar del ordenamiento procesal y en la que los criterios del procedimiento tienen asignado un papel más descollante (del derecho a la prueba al derecho de tutela judicial efectiva), y entre todos ellos - volvemos a insistir nosotros - el de la oralidad en especial. El juez, al final, tal y como hemos expuesto, valora libremente y en su conjunto todas las pruebas practicadas, tomando en consideración, por ejemplo, todos los perfiles de las declaraciones de parte y de terceros efectuadas por propia iniciativa o por impulso judicial, y así ocurre que también valora aquellos titubeos y "los silencios" de todos los intervinientes que en no pocas ocasiones resultan ser tan sonoros como probatorios por convincentes: sólo el referido plus de oralidad y de inmediación procesal que impera en la fase probatoria permite oír y valorar tales silencios a los efectos de posibilitar que el juez tenga - personal, íntima y directamente - todavía más elementos de convicción para conocer la verdad material a partir de la cual pueda construir su sentencia.

$\overline{96}$ Sentencia Tribunal Central de Trabajo de 2 de junio de 1979 (Aranzadi, 3159). 
Un juez sagaz resuelto y trabajador, que tenga cierta experiencia del alma humana, que disponga de tiempo y que no considere como mortificante trabajo de amanuense el empleado en recoger las pruebas, consigue siempre obtener del testigo, aún del más obtuso y del más reacio, alguna preciosa partícula de verdad. ${ }^{97}$

Y para terminar nuestra Ponencia deberíamos abrir un apartado de conclusiones, pero estimamos que resulta innecesario debido que las hemos presentado parcialmente a lo largo de estas páginas; laguna que, en todo caso, aprovechamos así:

Primero, para precisar que, una parte de nuestro planteamiento incluye postulados clásicos, pero no por ello - entendemos - merecedores de olvido alguno si lo que se pretende es que la actual etapa del ordenamiento jurídico laboral impregnada de pautas neoliberales y desreguladoras pase a mejor recuerdo y se recupere y profundice en favor de la esencia del mismo sin renunciar a cuantas reformas y adaptaciones se estime conveniente en materia laboral sustantiva y procesal" ${ }^{98}$ : Para avanzar en la construcción de una politica laboral progresista, es necesario revalorizar viejas prácticas" "99. Continúa siendo necesario mantener los referidos principios inspiradores del Derecho Procesal Laboral, los consiguientes principios del proceso laboral y los criterios de su procedimiento, pues se ha de tener presente que la desigualdad de las partes - materiales y procesales - siguen existiendo en los nuevos escenarios jurídico-laborales, y no en pocas con mayor intensidad: ¿han variado en el mismo sentido y con la misma intensidad los mecanismos jurídicos de protección del factor capital que los de protección del factor trabajo?; ¿frente a quién y cómo se debe y puede defender el trabajador ante empresarios interpuestos y situado en el marco de relaciones laborales triangulares?, dicho sea a modo de v.gr:; ¿cómo se defiende un trabajador autónomo dependiente económicamente frente a su empleador o empleadores que a su vez forman parte de un grupo de empresas tal que por lo demás no tiene un comité de grupo porque la legislación - sorprendentemente - no se lo exige?, ya para cambiar de tercio, también podemos preguntarnos, en el supuesto de acaso moral ¿existe igualdad entre el acosador y la víctima en términos probatorios? La incorporación al Derecho del trabajo de nuevas realidades laborales que se incorporan al Derecho del Trabajo - como las precitadas entre interrogantes a modo de v.gr. - no siempre se materializan con la debida tutela laboral sustantiva o material pues siempre se realizan en un contexto de tensión entre el expansionismo

97 CALAMANDREI, P. Elogio de los Jueces escrito por un Abogado. Madrid: Góngora, 1936, pág. 99.

98 A modo de $v$. gr: ARAMENDI SÁNCHEZ, P. Propuestas para reformar la Ley de Procedimiento Laboral. Revista Derecho del Trabajo y Seguridad Social, núm. 38, 2009, págs. 51-107.

99 ERMIDA URIARTE, O. La politica laboral de los gobiernos progresistas. Nueva Sociedad, núm. 211/2007, pág. 50. 
y la huida del Derecho del Trabajo. Es por ello que debemos acomodar a los nuevos tiempos y dar mayor fuste al derecho a la tutela judicial efectiva de los trabajadores - clásicos y nuevos - en el ámbito del orden social de la jurisdicción: el Derecho Social es y será siempre en cualquier momento en que se contemple un modelo de relaciones sociales inacabado y perpetuamente pendiente a un nuevo rearme que nunca jamás será el último o definitivo pues, "O directo do Trabalho nâo se esgota de uma só vez. e para sempre, visto que supôe mudanças continuas, e permanentes..."100; y ni en estos momentos de crisis económica, el "Estado no debe abandonar su labor de regulación de las relaciones de trabajo so pretexto de lograr un mayor crecimiento económico(....)" ${ }^{101}$, y nuestro Derecho del Trabajo debe contrarrestar aquellas nuevas propuestas neoliberales ${ }^{102}$ que no creen que es

suficiente reducir los derechos sustantivos [sino que], es necesario, igualmente limitarlo eliminar la intervención del Estado en el mundo de las relaciones de trabajo [confiando] esas relaciones al juego de las propias partes, en el marco de la libertad de los mercados económicos internos y de la globalización de la economía internacional. ${ }^{103}$

Segundo, para ratificarnos en que, en nuestra opinión, las previsiones constitucionales y el reflejo de las mismas en la legislación ordinaria dan pie para defender que: el derecho no debe ser siempre igual, sino desigual cuando regula relaciones no entre iguales sino entre desiguales (es el caso del Derecho del Trabajo y del Derecho Procesal Laboral); y que el proceso y el procedimiento siempre se puede y debe disciplinar de tal manera que el juzgador siempre sea imparcial pero no siempre neutral (es el caso del proceso y procedimiento laboral, y es el caso del juez social). En nuestra opinión, el intervencionismo social del Estado -y por derivación, el Derecho Social sustantivo y adjetivo- no se debe preocupar tanto de lograr la igualdad inter-partes como de (re)equilibar las desigualdades entre las mismas, pues este reto si no se supera con la ayuda del Estado no se superará debidamente; afirmación que dicha sea a modo de inventario dialéctico, se podría explicar mejor releyendo ahora la cita la cita que hemos transcrito en cabecera a modo de frontispicio

${ }^{100}$ MARTÍNEZ y GONZÁLEZ, A. Flexibiliçâo de normas e novos rumos do Directo do Trabalho, en: SÁVIO ZAINAGUI, D. y FREDIANI, Y. Novos rumos do Directo do Trabalho na América Latina. São Paulo: Editorial Ltda, 2003, pág. 131.

101 MANSUETI, HR. Derecho del Trabajo en el MERCOSUR. Buenos Aires: Edit. Ciudad Argentina., 1999, pág. 22.

102 RUSSOMANO, MV. Direito Procesual do Trabalho e reforma neoliberal das leis trabalhistas, en: XIIII Congreso Iberoamericano de Derecho del Trabajo y Seguridad Social, Panamá, 1998. T.3.

103 RUSSOMANO, MV. Procedimientos Laborales. En: "HERRERA CARBUCCIA, MR. Estudios de procedimiento laboral en Iberoamericana. Homenaje a Don Rafael Alburquerque. Republica Dominicana: Asociación Iberoamericana de Derecho del Trabajo y Librería Jurídica Internacional, 2007, pág. 8. 
de estas páginas, y en particular, teniendo en cuenta como en la misma su autor, la tratar del proceso laboral, interrelaciona la libertad con la igualdad de las personas en general: ${ }^{104}$ de la igualdad procesal a la que hemos dedicada nuestra atención en esta Ponencia, hasta la libertad como valor supremo no hay ni un paso; la igualad procesal es algo más que simplemente tal, es una parte esencial de la libertad de las personas.

Y tercero y último, para cerrar con opiniones doctrinales - españolas y dominicanas - que compartimos:

Todas las características que acaban de examinarse del proceso de trabajo y que facilitan tanto una mejor obtención de la verdad como un proceso más accesible, tiene su traducción en cuanto a las reglas del procedimiento en la importancia que en el proceso de trabajo se da al principio de oralidad y a sus consecuencias adicionales la inmediación, la publicidad y la concentración. Pero el tema también está muy relacionado con la valoración de la prueba y la unidad de instancia ${ }^{105}$; El órgano jurisdiccional puede tomar la iniciativa, tanto en la dirección formal del proceso como en el debate exhaustivo del caso, haciendo un uso adecuado y oportuno de sus facultades, dentro de la simplicidad y celeridad, propios del proceso en esta materia. ${ }^{106}$

Tenía - y en parte todavía tiene - razón el ya citado Profesor Antonio Menger, cuando en una de sus sugestivas obras trataba críticamente de la "pasividad del juez en el pronunciamiento civip", y afirmaba que "Hoy se sabe que no existe una desigualdad mayor que aquélla que consiste en tratar a los desiguales de un modo igual'. ${ }^{107}$

104 DE LA CUEVA, M. Derecho Mexicano del Trabajo. México: Porrúa, 1938, p. 28.

105 RODRIGUEZ-PIÑERO Y BRAVO-FERRER, M. Los principios informadores del proceso de trabajo, en: GUZMÁN, HB (ed. a cargo de): Derecho Procesal del Trabajo. Moca (Republica Dominicana): Editora Dalis. 2002, págs. Pág. 97.

106 HERNÁNDEZ RUEDA, L: Del régimen de la prueba, en: GUZMÁN, HB (ed. a cargo de): Derecho Procesal del Trabajo. Moca (Republica Dominicana): Editora Dalis. 2002, págs. Pág. 283.

107 MENGER, A. E1 Derecho civil y los pobres. Madrid: Librería General de Victoriano Suárez, 1898, págs. 118 a 123, y la cita puntual en pág. 119. 


\section{Referências Bibliográficas}

ALARCÓN CARACUEL, MR. Una valoración crítica global de la Ley de Bases de Procedimiento Laboral, en: ALARCÓN, MR. (Director): La reforma del Procedimiento Laboral. Madrid: Marcial Pons. 1989.

. (Coord.) Estudios sobre la Ley de Procedimiento Laboral de 1990. Madrid: Marcial Pons, 1991. ALONSO OLEA, M. y ALONSO GARCÍA, B. Derecho Procesal del Trabajo. Madrid: Thomson-Civitas., 2008. ARAMENDI SÁNCHEZ, P. Propuestas para reformar la Ley de Procedimiento Laboral. Revista Derecho del Trabajo y Seguridad Social, núm. 38/2009, págs. 51-107.

BAYLOS GRAU, A., CRUZ VILLALÓN, J. y FERNÁDEZ, MF. Instituciones de Derecho Procesal Laboral. Madrid: Trotta. 1995.

BAYLOS, A. La igualdad de las partes en el proceso laboral y la tutela judicial efectiva. Derecho Privado y Constitución, núm. 4/1994, págs. 107 a 129.

BENTHAM, J. Tratado de las pruebas judiciales. (traducción: Manuel Osorio) Granada: Comares, 2001 BLASCO PELLICER, A. Las medidas cautelares en el proceso laboral. Madrid: Civitas, 1996.

BOBBIO, N. Derecha e izquierda. (Tercera Edición). Madrid: Suma de Letras, S.L. (Punto de Lectura), marzo, 2001). BODAS MARTÍN, R. El juicio oral, en FOLGUERA CRESPO, J. (Director): El proceso laboral en la jurisprudencia del Tribunal Constitucional. Madrid: Consejo General del Poder Judicial. Cuadernos de Derecho Judicial, 1996.

CABRERA BAZÁn, J. La prueba en el proceso de trabajo. Revista de Política Social, núm. 82/1969.

CALAMANDREI, P. Proceso y Democracia. Lima: Ara Editores E.I.R.L, 2006

. Elogio de los Jueces escrito por un Abogado. Madrid: Góngora, 1936.

CARNELUTTI, M. La prova civile. Milano: Giuffrè. 1992

CASAS BAAMONDE, ME. La reforma de la legislación procesal laboral: los recursos en la Ley de Procedimiento Laboral. Revista española de Derecho del Trabajo, núm. 46/1991.

CRUZ VILLALÓN, J. Constitución y proceso de trabajo. En: “CRUZ, J. y VALDÉS, F.: Lecturas sobre la reforma del proceso laboral. Madrid:. Ministerio de Justicia., 1991, págs. 9 a 85. (Idem, en: Revista española de Derecho del Trabajo, núm. 38/1989).

. El limitado alcance de la supletoriedad de la Ley de Enjuiciamiento Civil de 2000 en el proceso laboral, en: MARTÍNEZ ABASCAL, VA. (Coord.): Nueva Ley de Enjuiciamiento Civil y Proceso Laboral . Madrid: Marcial Pons. 2002.

. La intervención de las representaciones colectivas en el proceso de trabajo, en ALDÉS DAL-RÈ, F: Lecturas sobre la reforma del proceso laboral. Madrid: Ministerio de Justicia. 1991.

CRUZ, J. y VALDÉS, F. Lecturas sobre la reforma del proceso laboral. Madrid: Ministerio de Justicia, 1991. DA CRUZ. EFRÉN BORRAJO. (Directos) Comentarios a las Leyes Laborales. La nueva Ley de Procedimiento Laboral (Real Decreto Legislativo 521/1990, de 27 de abril. Madrid: Editorial de Derecho Reunidas. 1990.

DE LA CUEVA, M.: Derecho Mexicano del Trabajo. México: Porrúa, 1938.

ERMIDA URIARTE, O. La política laboral de los gobiernos progresistas. Nueva Sociedad, núm. 211/2007. GÁRATE CASTRO, J. La tutela de los derechos fundamentales y libertades públicas por los tribunales laborales. Pontevedra: Edit. Revista Jurídica Galega, 1999.

GARCÍA BECEDAS, G. Los principios informadores del proceso laboral (Algunas reflexiones críticas en torno a la oralidad, celeridad y concentración. En: AA.VV.: El proceso laboral. Estudios en homenaje al Profesor Luis Enrique de la Villa Gil.Valladolid:. Lex Nova, 2001.

GARCÍA FERNÁNDEZ, M. Tutela jurisdiccional y carga de la prueba en el proceso de trabajo. Revista española de Derecho del Trabajo, núm. 15/1983

GARCÍA-PERROTE ESCARTÍN, I. La prueba en el proceso de trabajo. Madrid: Civitas, 1994. . Prueba y proceso laboral. Derecho Privado y Constitución. núm. 4/1994, págs. 163 a 221

GIL PLANA, J. La prueba en el proceso laboral. Disposiciones generales. Thomson-Aranzadi. Cizur Menor, 2005. GONZÁLEZ DÍAS, FA. Los medios de prueba en el proceso laboral. Madrid: Thomson-Civitas, 2005.

. Los medios de prueba en el proceso laboral. Madrid: Thomson-Civitas, 2005.

GUZMÁN, HB (ed. a cargo de) Derecho Procesal del Trabajo. Moca: Dalis. 2002, págs. 69 a 104. . (ed. a cargo de): Derecho Procesal del Trabajo. Moca: Editora Dalis. 2002. 
GUZMÁN, HB. Código de Trabajo anotado. Vol. II. Arts. 317 al 738. Santo Domingo: Instituto de Estudios del Trabajo, 2002, págs. 331 a 339.

HERnÁNDEZ RUEDA, L. Derecho Procesal del Trabajo. 3.ed. Santo Domingo, 1997.

Del régimen de la prueba, en: GUZMÁN, HB (ed. a cargo de): Derecho Procesal del Trabajo. Moca: Editora Dalis. 2002.

HERRERA CARBUCCIA, MR. (Coord.). Estudios de procedimiento laboral en Iberoamerica. Homenaje a Don Rafael Alburquerque. (Tomo I y Tomo II), Republica Dominicana: Asociación Iberoamericana de Derecho del Trabajo y Librería Jurídica Internacional, 2007.

. Importancia de la Unidad de Jurisprudencia Labaral. Análisis y Discusión. Gaceta Laboral, Vol. 12, núm. 1 de enero de 2006.

. La sentencia. en: "HERRERA CARBUCCIA, MR. (Coord.): Estudios de procedimiento laboral en

Iberoamerica Republica Dominicana: Asociación Iberoamericana de Derecho del Trabajo y Librería Jurídica Internacional. República Dominicana, 2007.

Informe de Investigación CIJUL (Centro de Información Jurídica en Línea - Convenio Colegio de Abogados y Universidad de Costa Rica), sobre "Principios rectores del proceso laboral" http://cijulenlinea.ucr.cr/condition.htm.

JUANES FRAGA, E. La prueba en el proceso de trabajo: novedades de la Ley de Enjuiciamiento Civil, en: "AA.VV.: El proceso laboral. Estudios en homenaje al Profesor Luis Enrique de la Villa Gil. Valladolid: Lex Nova., 2001.

LUELMO MILLÁN, MA. RABANAL CARBAJO, P. Los principios inspiradores del proceso laboral. Madrid: McGraw-Hill, 1999.

MANSUETI, HR. Derecho del Trabajo en el MERCOSUR. Buenos Aires: Ciudad Argentina, 1999. MARTÍN VALVERDE, A. La Parte General de la Ley de Procedimiento Laboral de 1990, en, "ALARCÓN, MR. (Coord.): Estudios sobre la Ley de Procedimiento Laboral de 1990. Madrid: Marcial Pons, 1991.

MARTÍNEZ y GONZÁLEZ, A. Flexibiliçâo de normas e novos rumos do Directo do Trabalho, en SÁVIO ZAINAGUI, D. y FREDIANI, Y. Novos rumos do Directo do Trabalho na América Latina. São Paulo: Editorial Ltda, 2003.

MENGER, A. El Derecho civil y los pobres. Madrid: Librería General de Victoriano Suárez, 1898.

MONEREO PÉREZ, JL. La carga de la prueba en los despidos lesivos de los derechos fundamentales. Valencia: Tirant lo Blanch, 1996.

MONTERO AROCA, J. Particularidades de la prueba en el proceso laboral. Procedimiento, objeto y medios. Especial referencia a la prueba documenta, En AGUSTÍ JULIÀ, J: La prueba en el proceso laboral. Madrid: Cuadernos de Derecho Judicial, nún. XXIII/1997. Escuela Judicial. Consejo General del Poder Judicial, 1998.

MONTOYA MELGAR, A. El proceso laboral y sus reformas en España, En: El Derecho del Trabajo en los albores del siglo XXI. Memorias y Comunicaciones del Congreso Internacional del Derecho del Trabajo. Isla Margarita. Venezuela Abril-Mayo de 2007. Revista Derecho del Trabajo, núm. 3 (extraordinario) de 2007 MUÑOZ CAMPOS, J. El principio de igualdad en el proceso laboral. En: Jornadas sobre cuestiones actuales de enjuiciamiento laboral". Madrid: Instituto de Estudios Laborales y de la Seguridad Social. Ministerio de Trabajo y de la Seguridad Social. 1985.

MURCIA CLAVERÍA, A. La representación voluntaria en el proceso laboral. Madrid: Marcial Pons, 1994.

MURGAS TORRAZZA, R. La tutela judicial contra los despidos nulos por discriminación. Experiencia comparada. Revista Derecho del Trabajo, núm. 3 (extraordinaria) 2007 (Venezuela), págs. 379 a 395.

ORTIZ LALLANA, MC. La intervención del sindicato en el proceso de trabajo. Madrid: CES. Madrid, 1994. OSSORIO y GALLARDO, A. El alma de la toga. Buenos Aires: Valleta Ediciones. Argentina.

PALOMEQUE, C. Sindicato y proceso de trabajo. Revista de Política Social, núm 122/1979

PALOMINO, TA. Derecho del Trabajo en el siglo XXI. Lima (Perú): Editorial Juris Laboral, 1994.

PASCO COSMÓPOLIS, M. Principio protector en el proceso laboral, En HERRERA CARBUCCIA, MR. (Coord.). Estudios de Procedimiento Laboral en Iberoamerica. Republica Dominicana: Asociación Iberoamericana de Derecho del Trabajo., 2007, Tomo I

PÉREZ AMORÓS, F. El Derecho del Trabajo un derecho revolucionario en defensa del derecho a la paz. En: PALOMINO, TA.: El Derecho del Trabajo Iberoamericano. Libro homenaje al Dr. Baltasar Cavazos Flores. Lima (Perú): Imprenta Gráfica E\&N. Asociación Iberoamericana de Derecho del Trabajo y de la Seguridad Social, 2005. 
PÉREZ AMORÓS, F. El intervencionismo estatal y el Derecho del Trabajo: la Inspección de Trabajo y Seguridad Social. En ESPUNY TOMÁS, MJ. y PAZ TORRES, O. (Coords.): La Inspección de Trabajo 19062006. Valencia: Tirant lo Blanch. 2008, págs. 11 a 38.

. Nociones sobre el recurso de casación para la unificación de la doctrina en el derecho procesal español. En: HERRERA CARBUCCIA, MR. (Coord.): Estudios de procedimiento laboral en Iberoamericana. Homenaje a Don Rafael Alburquerque. Republica Dominicana: Asociación Iberoamericana de Derecho del Trabajo y Librería Jurídica Internacional., 2007, Tomo II ; ROJO, E. y SAURA, L. Formularios procesales laborales. Comentarios y jurisprudencia. $2^{\mathrm{a}}$. ed. Barcelona: Bosch, Casa Editorial, 1991

RODRIGUEZ-PIÑERO y BRAVO-FERRER, M. Los principios informadores del proceso de trabajo. En GUZMÁN, HB (ed. a cargo de): Derecho Procesal del Trabajo. Moca (Republica Dominicana): Editora Dalis. 2002.

RODRÍGUEZ-PIÑERO y BRAVO-FERRER; M. Proceso de trabajo y justicia constitucional, En: AA.VV. El proceso laboral. Estudios en Homenaje al Profesor Luis Enrique de la Villa Gil. Valladolid: Lex Nova, 2001. RODRÍGUEZ-PIÑERO, M. Derecho del Trabajo y proceso. Murcia: Publicaciones Escuela Social de Murcia, 1972

. Jurisdicción de trabajo y sistema constitucional. En ALARCÓN CARACUEL, MR: La reforma del procedimiento Laboral. Madrid: Marcial Pons. 1989. . Sobre los principios informadores de del proceso de trabajo. Revista de Política Social, núm. 81/1969. Sobre los principios informativos del proceso de trabajo. Revista de Política Social, núm. 81/1969

RUIZ MOREnO, AG. Nuevo Derecho de la Seguridad Social. (Séptima edición). México: Porrúa. 2003. . Nuevo Derecho de la Seguridad Social. México: Porrúa. 2003 (Séptima edición).

RUSSOMANO, MV. Decálogo del Proceso Laboral. Presentación de un autor y su obra, por SERRANO CARVAJAL, J. Madrid: Universidad Complutense. Facultad de Derecho. Sección de Publicaciones. Madrid, 1986. RUSSOMANO, MV. Direito Procesual do Trabalho e reforma neoliberal das leis trabalhistas, en XIIII Congreso Iberoamericano de Derecho del Trabajo y Seguridad Social, Panamá, 1998. T.3.

Procedimientos Laborales, En HERRERA CARBUCCIA, MR.: Estudios de procedimiento

laboral en Iberoamericana. Homenaje a Don Rafael Alburquerque. Republica Dominicana: Asociación Iberoamericana de Derecho del Trabajo y Librería Jurídica Internacional, 2007.

SAÉZ LARA, C. La tutela judicial efectiva y el proceso laboral. Madrid: Thomson-Civitas. 2004.

SALINAS MOLINA, F. Medidas cautelares y prueba anticipada. En AGUSTÍ JULIÀ, J. La prueba en el proceso laboral. Madrid: Cuadernos de Derecho Judicial (1997). Escuela Judicial. Consejo General del Poder Judicial, 1998, págs. 113 a 176.

. Principios de la nueva regulación de la ejecución. En: ALARCÓN, MR. (Coord.): Estudios de la Ley de Procedimiento Laboral de 1990. Madrid:. Marcial Pons, 1991

SALVIOLI, G. El derecho civil y el proletariado. Edición de Bartolomé Clavero. Sevilla: Edita. Secretariado de Publicaciones de la Universidad de Sevilla. 1979.

SANZ TOMÉ F. La prueba en el proceso laboral. Comentarios-Sentencias. Valladolid: Lex Nova, 1990, Tomo I

SÁVIO ZAINAGHI, D. A soluçao extrajudicial dos conflitos trabalhistas no Brasil. São Paulo: Editora LTR. 2004.

SEGALÉS, J. La prueba en el proceso laboral. Tras la Ley 1/2000 de Enjuiciamiento civil. Granada: Comares. 2002.

VALDÉS DAL-RÉ, F.: El nuevo proceso laboral. Relaciones Laborales, núm. 14/1990

VALLADARES CASTILLO, F. Derecho Procesal del Trabajo. Managua: Bitecsa, 2000

YSAS MOLINERO, H. La participación de los sindicatos en las funciones normativas de los poderes públicos. Una comparación entre España y Francia. Tesis Doctoral. Barcelona: Universidad Autónoma de Barcelona, febrero 2009, pág. 195 (consulto original inédito; en prensa). 